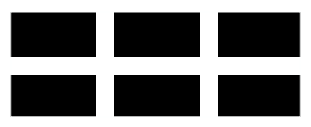

THE WILLIAM DAVIDSON INSTITUTE AT THE UNIVERSITY OF MICHIGAN BUSINESS SCHOOL

\title{
Do Regional Integration Agreements Increase Business-Cycle Convergence? Evidence From APEC and NAFTA
}

By: Viviana Fernandez and Ali M. Kutan

William Davidson Institute Working Paper Number 765

April 2005 


\title{
DO REGIONAL INTEGRATION AGREEMENTS \\ INCREASE BUSINESS-CYCLE CONVERGENCE? \\ EVIDENCE FROM APEC AND NAFTA
}

\author{
Viviana Fernandez \\ Center for Applied Economics (CEA)/Department of Industrial Engineering \\ University of Chile \\ Ali M. Kutan ${ }^{* *}$ \\ Department of Economics and Finance \\ Southern Illinois University Edwardsville \\ and \\ The William Davidson Institute \\ The University of Michigan Business School
}

\begin{abstract}
Using monthly industrial sector data from January 1971 to March 2004, we test for business cycles convergence among the major APEC members: Japan, South Korea, Malaysia, Mexico, USA, and Canada. In addition, we examine the synchronization of business cycles among Australia, Japan, and South Korea, based on the quarterly data for the 1957-2003 period, as well as among the different economic sectors of the NAFTA countries from January 1970 through March 2004. We apply different techniques to identify business cycles. In particular, we propose a new trend-cycle decomposition method based on wavelet analysis. The results show that convergence of business cycles of Asia-Pacific countries is far from complete, but joining the APEC has increased the mean correlation of industrial production cycles of the member economies. On the other hand, although some economic sectors of the NAFTA countries already exhibited some degree of business cycle co-movement even during pre-NAFTA period, the volatility of pair-wise correlation of business cycles declined during NAFTA. In addition, we conclude that, in general, the transmission of business cycles is relatively slow, and, consequently, business cycles appear to be asynchronous.
\end{abstract}

JEL classification: B41, E32.

Keywords: business-cycles convergence, wavelets, APEC, NAFTA.

\footnotetext{
*Postal: Avenida Republica 701, Santiago-Chile. E-mail: vfernand@dii.uchile.cl. Funds provided by FONDECYT Grant No. 1050486 and by an institutional grant of the Hewlett Foundation to CEA are greatly acknowledged.

** Postal: Alumni Hall-3143, Department of Economics and Finance Southern Illinois University Edwardsville. Edwardsville, Illinois 62026. E-mail: akutan@siue.edu.
} 


\section{Introduction}

The issue of business cycles convergence has received a great deal of attention in recent years, mainly motivated by the economic and monetary union in Europe (EMU). According to Mundell (1961)'s optimal currency area (OCA) theory, two countries or regions will benefit from a monetary union if they share similar business cycles, trade intensively, and rely on efficient adjustment mechanisms (e.g., labor mobility, price flexibility of production factors, and government transfers) to smooth out asymmetric shocks. Consequently, considerable effort has been made to quantify the synchronicity of business cycles among the core members of the European Union (EU) and the new ten EU members that joined as of May 2004. There are two good reasons for such enlargement efforts. First, if business cycles of the Euro-zone countries are asynchronous, then the monetary union may not be as beneficial. Second, the new EU countries should not probably rush to adopt the Euro unless their economies meet the conditions set by the OCA theory.

Artis and Zhang (1997, 1999), Massman and Mitchell (2003), Firdrmuc and Korhonen (2004), and Babetskii (2005) examine business cycles convergence for European countries. Artis and Zhang (1997) analyze how the establishment of the Exchange Rate Mechanism (ERM) of the European Monetary System (EMS) affected international business cycles ${ }^{1}$. Using U.S. and German business cycles as key benchmarks, they show that business cycles of the ERM countries became more synchronized with the German cycle, and less synchronized with the US cycle during the ERM period. Considering a larger sample of countries and a longer time-period, Artis and Zhang (1999) confirmed their earlier findings that a higher degree of business cycles synchronization is associated with less volatility exchange rates. However, more recent studies find mixed evidence about business cycles convergence of the Euro-zone countries. For example, Massman and Mitchell (2003), using different trend-cycle decomposition methods and HardingPagan (2001)'s turning point rule, show that over the 1960-2001 period the Euro zone countries alternated many times between periods of convergence and divergence of business cycles.

More recent studies have focused on business cycle correlation of the Euro zone and Central and Eastern European countries (CEECs). Fidrmuc and Korhonen (2004) survey about

\footnotetext{
1 The EMS was established in 1979 to stabilize foreign exchange and inflation rates among the member countries. At the beginning of 1999, the core members and additional members adopted the euro as a single currency.
} 
thirty studies with nearly 350 point estimates of business-cycle correlation between the CEECs and the Euro zone. They conclude that several CEECs already exhibit high correlation with the Euro-zone business cycles; however, correlation coefficients are sensitive to estimation methodologies. Babetskii (2005) analyzes trade intensity and synchronization of shocks between 10 CEEC countries against both the core European Union members and Germany. Based on Blanchard and Quah (1989)'s bi-variate structural VAR methodology, he finds that trade integration leads to a higher symmetry of demand shocks, but the effect of the integration on supply shocks is ambiguous. Furthermore, he reports that lower exchange rate volatility leads to higher convergence of demand shocks with no significant effect on supply shock convergence.

In a recent article on real convergence and Euro adoption in Central and Eastern Europe, Frankel (2004) argues that the growing trade links with the Euro land will translate into growing cyclical convergence. This implies that new European Union members may better qualify for the optimum currency area criteria in the future than now.

Recent studies connected with our study are Selover (1999), Torres and Vela (2003), and Shin and Wang (2004). Selover (1999) investigates the international transmission of business cycles among the Association of Southeast Asian Nations (ASEAN) countries of Indonesia, Malaysia, Philippines, Singapore and Thailand, and between the ASEAN nations and their major trading partners, the U.S., Australia, Japan, and the European Union. Based on vector autoregression analysis, he finds weak evidence of transmission of business cycles among the ASEAN economies, and between the ASEAN economies and their major trading partners. Selover argues that the explanation for such weak evidence can be found in commodity price fluctuations, wars, and major political disturbances, which have interfered with the natural course of business cycles.

Torres and Vela (2003) study the consequences of regional economic integration between Mexico and the United States. They conclude that, as the manufacturing sectors of the two nations have become more integrated, their business cycles have become more synchronized. And, as a result, the volatility of the Mexican trade balance has declined. Shin and Wang (2004), in turn, focus on the synchronization Korea's business-cycle with those of other Asian economies. They conclude that intra-industry trade is the major channel by which such synchronization can be achieved. In addition, they find that increasing trade itself does not necessarily lead to more synchronization of business cycles. 
Our study focuses on business cycles convergence among the economies that have recently signed regional trade arrangements: The Asia-Pacific Economic Cooperation (APEC) and North American Free Trade Agreement (NAFTA). Our methodology extends that of Massman and Mitchell (2003). Specifically, we present a new trend-cycle decomposition method based on wavelet analysis. The advantage of the wavelet method over other commonly-used approaches is that it allows for decomposing a time series into orthogonal components, where each individual component is associated with a different time-scale. The wavelet approach is able to clearly distinguish between a trend and a cycle component by assigning each component a different time dimension. We provide evidence using industrial sector data for the APEC and NAFTA countries. We also analyze the existence of business cycles convergence among different economic sectors of the NAFTA countries before and after the signing of the agreement. Looking forward, our estimation results show that full business cycles convergence has not been reached among the APEC or NAFTA members. Indeed, in some cases, we find that the degree of synchronicity of business cycles across countries has even weakened over time.

This article is organized as follows. Section 2 gives a brief background on the wavelet analysis and describes the three trend-cycle decomposition methods used in this study. Section 3 presents our estimation results for the APEC and NAFTA countries. Finally, Section 4 concludes.

\section{Methodological issues}

\section{$2.1 \quad$ Wavelets}

Our study presents an alternative methodology to decompose a time series into a cycle and trend component, using wavelet analysis. This method, which is a refinement of the Fourier analysis that was developed in the late 1980's, offers a suitable methodology for decomposing a series into orthogonal components with different frequencies. Recent applications of the wavelet methods have dealt with the permanent income hypothesis, the estimation of systematic risk of an asset (beta), and the interaction between emerging and developed stock markets and others (e.g., Ramsey and Lampart (1998), Ramsey (1999, 2002), Li and Stevenson (2001), Gençay, Whitcher, and Selcuk (2001, 2003, 2004), Hong and Kao (2004), and Whitcher (2004)). In this paper, we use this method to investigate business cycles convergence. 
In particular, a wavelet allows for decomposing a signal (e.g., a time series of industrial production, inflation, stock returns) into high and low frequency components (see, for instance, Bruce and Gao, 1996; Percival and Walden, 2000). High frequency (irregular) components describe the short-run dynamics, whereas low-frequency components represent the long-term behavior of a signal. Identification of the business cycle involves retaining intermediatefrequency components of a time series. That is, we disregard very high- and very low-frequency components. For instance, it is customary to associate a business cycle with cyclical components between 6 and 32 quarters (e.g., Baxter and King, 1999).

Father wavelets $(\phi)$ are good at representing the smooth and low-frequency parts of a signal, whereas mother wavelets $(\psi)$ are good at representing the detailed and high-frequency parts of a signal. The most commonly used wavelets are the orthogonal ones. In particular, the orthogonal wavelet series approximates a continuous signal $f(t)$ as

$$
\mathrm{f}(\mathrm{t}) \approx \sum_{\mathrm{k}} \mathrm{s}_{\mathrm{J}, \mathrm{k}} \phi_{\mathrm{J}, \mathrm{k}}(\mathrm{t})+\sum_{\mathrm{k}} \mathrm{d}_{\mathrm{J}, \mathrm{k}} \psi_{\mathrm{J}, \mathrm{k}}(\mathrm{t})+\sum_{\mathrm{k}} \mathrm{d}_{\mathrm{J}-1, \mathrm{k}} \psi_{\mathrm{J}-1, \mathrm{k}}(\mathrm{t})+\ldots+\sum_{\mathrm{k}} \mathrm{d}_{1, \mathrm{k}} \psi_{1, \mathrm{k}}(\mathrm{t})
$$

where $\mathrm{J}$ is the number of multi-resolution components or scales, and $\mathrm{k}$ ranges from 1 to the number of coefficients in the corresponding component. The coefficients $\mathrm{s}_{\mathrm{J}, \mathrm{k}}, \mathrm{d}_{\mathrm{J}, \mathrm{k}}, \ldots, \mathrm{d}_{1, \mathrm{k}}$ are the wavelet transform coefficients, whereas the functions $\phi_{\mathrm{j}, \mathrm{k}}(\mathrm{t})$ and $\psi_{\mathrm{j}, \mathrm{k}}(\mathrm{t})$ are the approximating wavelet functions.

Applications of wavelet analysis commonly utilize a discrete wavelet transform (DWT). The DWT calculates the coefficients of the approximation in (1) for a discrete signal of final extent, $f_{1}, f_{2}, . ., f_{n}$. That is, it maps the vector $\mathbf{f}=\left(f_{1}, f_{2}, \ldots, f_{n}\right)^{\prime}$ to a vector $\omega$ of $n$ wavelet coefficients that contains $s_{\mathrm{J}, \mathrm{k}}$ and $\mathrm{d}_{\mathrm{j}, \mathrm{k}}, \mathrm{j}=1,2, \ldots$, J. The $\mathrm{s}_{\mathrm{J}, \mathrm{k}}$ are called the smooth coefficients and the $d_{j, k}$ are called the detail coefficients. Intuitively, the smooth coefficients represent the underlying smooth behavior of the data at the coarse scale $2^{\mathrm{J}}$, whereas the detail coefficients provide the coarse scale deviations from it.

When the length of the data $n$ is divisible by $2^{J}$, there are $n / 2$ coefficients $d_{1, k}$ at the finest scale $2^{1}=2$. At the next finest scale, there are $n / 2^{2}$ coefficients $d_{2, k}$. Similarly, at the coarsest scale, there are $\mathrm{n} / 2^{\mathrm{J}} \mathrm{d}_{\mathrm{J}, \mathrm{k}}$ coefficients and $\mathrm{n} / 2^{\mathrm{J}} \mathrm{s}_{\mathrm{J}, \mathrm{k}}$ coefficients. Altogether, there are $\mathrm{n}\left(\sum_{\mathrm{i}=1}^{\mathrm{J}} \frac{1}{2^{\mathrm{i}}}+\frac{1}{2^{\mathrm{J}}}\right)=\mathrm{n}$ coefficients. The number of coefficients at a given scale is related to the 
width of the wavelet function. For instance, at the finest scale, it takes $n / 2$ terms for the functions $\psi_{1, k}(t)$ to cover the interval $1 \leq \mathrm{t} \leq \mathrm{n}$. In other words, at the lowest scales, more details of the original time series will be captured.

Expression (1) can be rewritten as

$$
\mathrm{f}(\mathrm{t}) \approx \mathrm{S}_{\mathrm{J}}(\mathrm{t})+\mathrm{D}_{\mathrm{J}}(\mathrm{t})+\mathrm{D}_{\mathrm{J}-1}(\mathrm{t})+\ldots+\mathrm{D}_{1}(\mathrm{t})
$$

where $S_{J}(t)=\sum_{k} S_{J, k} \phi_{J, k}(t)$ and $D_{J}(t)=\sum_{k} d_{j, k} \psi_{J, k}(t)$ are denominated the smooth and detail signals, respectively. The terms in expression (2) represent a multi-resolution decomposition (MRD) of the signal into the orthogonal components $S_{J}(t), D_{J}(t), D_{J-1}(t), . ., D_{1}(t)$ at different scales. For instance, when analyzing monthly data, wavelet scales are such that scale 1 is associated with 2-4 month dynamics, scale 2 is with $4-8$ month dynamics, scale 3 is with 8-16 month dynamics, and so on.

In other to illustrate these ideas, Figure 1(a) depicts a MRD decomposition of the Japanese production index for six decomposition levels. The time series leveled as "sum" represents the raw production index, whereas D1 through S6 are the orthogonal components into which the raw data is decomposed. For instance, the D1 crystal captures high-frequency or noisy components of the series associated to short-term dynamics. As the scale $\mathrm{J}$ increases, we are able to capture the lower-frequency parts of the series. In particular, the trend component is mainly captured by the S6 crystal. Therefore, in order to construct an estimate of the business-cycle, we get rid of the low scale (high frequency) noise existing in D1 and D2, and exclude the low frequency base-line drift captured by S6. This is further discussed in the next section.

\subsection{Trend-cycle decomposition methods}

In this paper, we utilize three trend-cycle decomposition methods to check the sensitivity of the results to using different methods: linear de-trending, a univariate unobserved-components structural model, and wavelet analysis. As mentioned earlier, the latter represents a new methodology for obtaining the business-cycle of a time series, which has not been previously used in the literature.

The linear de-trending method is the easiest method to implement. This consists of running a linear regression of a time series $\left(\mathrm{y}_{\mathrm{t}}\right)$, such as a production index, against a constant 
term and a deterministic time trend $(\mathrm{t})$. The estimated cycle component is given by $\mathrm{y}_{\mathrm{t}}-\hat{\beta} \mathrm{t}$, where $\beta$ is the coefficient on t. This method has been a standard tool for separating trends from cycles in the past. However, many macroeconomic series contain unit roots that are not removed by this method (see, for instance, Baxter and King's (1999) discussion). It will not therefore be a suitable tool for trend-cycle decomposition in many cases, and therefore inferences based on this approach should be made cautiously.

Unlike the linear de-trending method, the basic univariate unobserved-components structural model, which is estimated by the Kalman filter approach, allows for the presence of a stochastic trend in the data. In particular, this model is given by

$$
\mathrm{y}_{\mathrm{t}}=\mu_{\mathrm{t}}+\psi_{\mathrm{t}}+\xi_{\mathrm{t}}
$$

where $\mu_{\mathrm{t}}$ is the unobserved trend component, $\psi_{\mathrm{t}}$ is the unobserved cycle component, and $\xi_{\mathrm{t}}$ is the unobserved irregular component. The non-stationary trend component $\mu_{\mathrm{t}}$ takes the form of a local linear trend:

$$
\begin{gathered}
\mu_{\mathrm{t}+1}=\mu_{\mathrm{t}}+\beta_{\mathrm{t}}+\eta_{\mathrm{t}} \\
\beta_{\mathrm{t}+1}=\beta_{\mathrm{t}}+\varepsilon_{\mathrm{t}}
\end{gathered}
$$

where $\eta_{\mathrm{t}} \sim \mathrm{N}\left(0, \sigma_{\eta}^{2}\right)$ and $\varepsilon_{\mathrm{t}} \sim \mathrm{N}\left(0, \sigma_{\varepsilon}^{2}\right)$ are both white-noise processes, $\mu_{1} \sim \mathrm{N}(0, \omega)$ and $\beta_{1} \sim \mathrm{N}(0, \omega)$, with $\omega$ large.

The stochastic cycle component, which is given by $y_{t}-\mu_{t}=\psi_{t}+\xi_{t}$, can be expressed in terms of sine and cosine functions. (See Zivot and Wang, 2003, chapter 14, for details). If $\sigma_{\varepsilon}^{2}=0$, $\mu_{\mathrm{t}}$ follows a random-walk process with drift $\beta_{1}$. This is the assumption we make in our computations. When $\sigma_{\eta}^{2}=\sigma_{\varepsilon}^{2}=0, \mu_{\mathrm{t}}$ follows a deterministic trend, and both the unobservedcomponent and de-trending methods yield the same trend-cycle decomposition.

In the case of the wavelet filter, for monthly data the business cycle is reconstructed from the crystals at scales 3 through 6 (i.e., 8-128 month dynamics). For quarterly data, we define the cycle as the time series reconstructed from scales 2, 3, and 4 (i.e., 4-32 quarters dynamics). Such choice was based upon removing the noise in data associated with its short-term dynamics, and 
excluding the long-term trend associated to the highest scale. Eliminating the slow-moving components of the series should help eliminate the presence of a unit root in data. ${ }^{2}$

On the other hand, given that the orthogonal wavelet decomposition tends to do poorly at the first and last data points, we set a number of scales that is not too large. As J gets larger, the number of coefficients in the upper scales (equal to $n / 2^{J}$ ) gets smaller due to a fixed number of observations. And, therefore, the reconstructed series will capture only the very lowest frequency information contained in the time series of interest.

Figure 1(b) illustrates the use of the three decomposition methods for the Japanese industrial production index. The left-hand side panel depicts the trend component whereas the right-hand side panel depicts the cyclical component of the index, according to each of the three business-cycle filters. First of all, according to the Kalman and wavelet filters, we see that the trend of the data is not exactly linear. Second, there is a close correspondence between these two filters - except for the first and last data points, where the wavelet reconstruction of the trend is poorer.

When it comes to the cyclical component, the linear de-trending method yields a very jagged estimate, as it puts a heavier weight on the high-frequency components of the data. By contrast, the wavelet filter yields the smoothest cycle estimate, because it removes most of the noise associated with short-term dynamics. Again, for intermediate data points over the sample period, the Kalman and wavelet filters resemble one another to a great extent.

We note that the choice of the wavelet function affects our estimate of business cycles. We tried other orthogonal wavelets as well. For instance, among the daublet functions, another possibility was the haar function. This yielded a very jagged estimate, which resembled that of the linear de-trending method. Therefore, we chose an orthogonal wavelet function (daublet-8 orthogonal) that removed most of the irregular components, but that it did not yield an excessively smooth cyclical component. In the rest of the paper, we used this wavelet function.

\footnotetext{
${ }^{2}$ For the series we deal with in the empirical section of the article, we checked that we had successfully removed the unit roots from the cyclical component by using the wavelet filter.
} 


\section{Empirical results for convergence}

\subsection{Asia-Pacific Economic Cooperation (APEC)}

APEC is a forum established in 1989 for facilitating economic growth, cooperation, trade and investment in the Asia-Pacific region. Unlike the World Trade Organization, or other multilateral trade bodies, APEC has no treaty obligations required of its participants. ${ }^{3}$ Our sample consists of the following six APEC members for which we were able to get a complete data set on industrial production for the January 1971-March 2004 period: Japan, South Korea, Malaysia, Mexico, USA, and Canada. All these countries joined APEC in November 1989, except for Mexico, which became a member in November 1993. Industrial production data was obtained from the International Monetary Fund's International Financial Statistics (IFS) CD Rom data base.

Table 1 presents unit-root tests for the industrial production indices. The results indicate that the levels of the series are characterized by a stochastic trend (i.e., unit root), whereas their first differences are integrated of order 0 . The log transformation modifies the magnitude of the Augmented Dickey-Fuller (ADF) test noticeably in some cases, but the conclusions with respect to the existence of unit roots are overall unchanged. The only exception is in the case of Malaysia for which we reject the existence of a unit root at the 5-percent level when considering the natural logarithm of the industrial production index. When we look at the first differences and their logs, the magnitudes of the ADF statistics are fairly similar and, hence, we strongly reject the existence of unit roots for level data and conclude that the growth rates are integrated of order 0 or stationary.

Once we identify the cycle component of each index, we compute pair-wise correlation coefficients of monthly industrial production growth rates, using an h-period rolling window. We follow Massmann and Mitchell (2003)'s methodology, which consists of the following steps. First, for a sample of $n$ countries, there are $n(n-1) / 2$ pair-wise correlation coefficients. For each time $t$, the $j$-th correlation coefficient $\left(\rho_{j t}\right)$ is computed using an h-month window, where $j=1, .$. ,

\footnotetext{
${ }^{3}$ APEC has 21 members which account for more than a third of the world's population, approximately 60 percent of world GDP, and about 47 percent of world trade. APEC's member economies are Australia, Brunei Darussalam, Canada, Chile, People's Republic of China, Hong Kong, Indonesia, Japan, Republic of Korea, Malaysia, Mexico, New Zealand, Papua New Guinea, Peru, The Republic of the Philippines, The Russian Federation, Singapore, Chinese Taipei, Thailand, United States of America, and Viet Nam (source: www.apec.org).
} 
$n(n-1) / 2$. Next, for each $t$, we compute the sample mean of the $n(n-1) / 2$ correlation coefficients $\left(\mathrm{m}_{\mathrm{t}}\right)$ and its corresponding variance, and the variance of the correlation coefficients $\left(\mathrm{v}_{\mathrm{t}}^{2}\right)$ :

$$
\begin{aligned}
& \mathrm{m}_{\mathrm{t}}=\frac{1}{\mathrm{~N}} \sum_{\mathrm{j}=1}^{\mathrm{N}} \hat{\rho}_{\mathrm{jt}} \quad \operatorname{var}\left(\mathrm{m}_{\mathrm{t}}\right)=\frac{1}{\mathrm{~N}^{2}} \sum_{\mathrm{j}=1}^{\mathrm{N}} \operatorname{var}\left(\hat{\rho}_{\mathrm{jt}}\right)+2 \sum_{\mathrm{i}=1}^{\mathrm{N}-1} \sum_{\mathrm{j}=\mathrm{i}+1}^{\mathrm{N}} \operatorname{cov}\left(\hat{\rho}_{\mathrm{it}}, \hat{\rho}_{\mathrm{jt}}\right) \\
& \mathrm{v}_{\mathrm{t}}^{2}=\frac{1}{\mathrm{~N}-1} \sum_{\mathrm{j}=1}^{\mathrm{N}}\left(\hat{\rho}_{\mathrm{jt}}-\mathrm{m}_{\mathrm{t}}\right)^{2}
\end{aligned}
$$

where $\mathrm{N} \equiv \mathrm{n}(\mathrm{n}-1) / 2$.

If converges exists, then $\mathrm{m}_{\mathrm{t}}$ should approximate 1 and its variance, $\mathrm{v}_{\mathrm{t}}^{2}$, should approach to zero as the sample size gets larger. We consider the three trend-cycle decomposition methods depicted in Figure 2. In order to have a benchmark for our trend-cycle decomposition methods, we follow Massman and Mitchel and apply Harding and Pagan’s turning-point analysis (2001). This stipulates that phases last at least two quarters, and complete cycles last at least five quarters. In other words, for monthly data, a peak in the growth rate will be observed at time $t^{*}$ if

$$
\left.\begin{array}{l}
\Delta_{\mathrm{i}} \dot{\mathrm{X}}_{\mathrm{t}^{*}}>0 \\
\Delta_{\mathrm{i}} \dot{\mathrm{X}}_{\mathrm{t}^{*}+\mathrm{i}}<0
\end{array}\right\} \quad \mathrm{i}=1, \ldots, 6
$$

where $\dot{x}_{t}$ is the growth rate of the $\left\{x_{t}\right\}$ process (e.g., industrial production index), and $\Delta_{\mathrm{i}} \dot{\mathrm{x}}_{\mathrm{t}^{*}}=\dot{\mathrm{x}}_{\mathrm{t}^{*}}-\dot{\mathrm{x}}_{\mathrm{t}^{*}-\mathrm{i}}, \Delta_{\mathrm{i}} \dot{\mathrm{x}}_{\mathrm{t}^{*}+\mathrm{i}}=\dot{\mathrm{x}}_{\mathrm{t}^{*}+\mathrm{i}}-\dot{\mathrm{x}}_{\mathrm{t}^{*}}, \mathrm{i}=1, \ldots, 6$.

Trend-cycle decomposition by wavelets and the Kalman filter was carried out with the SPlus FinMetrics 1.0 and Wavelets 2.0 modules. Estimation of $\mathrm{m}_{\mathrm{t}}$ and $\operatorname{var}\left(\mathrm{m}_{\mathrm{t}}\right)$ was done with the generalized method of moments (GMM) routine of TSP 4.5. Figure 3 and Table 3 show our results, taking a 3.5-year rolling window ${ }^{4}$. The sample mean correlation coefficient averages only 0.031 and 0.041 , according to the linear de-trending and Kalman filter methods, respectively. The wavelet method systematically yields a greater estimate of the mean correlation, but with a greater variance. This result is not surprising given the discussion of the previous section. Indeed, because the wavelet filter captures more of the low-frequency

\footnotetext{
${ }^{4}$ Massmann and Mitchell (2003) utilize this window size for many of their computations.
} 
components of the series, the correlation between cyclical components and its corresponding variance will be higher as most of the variability of the production indices lies at lower frequencies.

If business cycles convergence exists, we would expect an inverse relation between mean correlation coefficients and their variances. According to Figure 4, such pattern is indicated only by the wavelet trend-cycle decomposition and, to some degree, by the Kalman filter approach. This finding indicates the importance of using different techniques to measure business cycles. Figure 5 depicts the four mean correlation estimates, including Harding-Pagan's. Over the Asian crisis, the mean correlation became smaller and even negative, according to the Harding-Pagan's procedure. Indeed, industrial production in Japan, Malaysia, and South Korea was more severely hurt by the economic crisis than in Canada, Mexico, and the US. Towards the end of 1999, all the four methods yield that the mean correlation becomes again positive, and generally greater than the coefficient in the rest of the sample period. In other words, in the past few years, industrial production growth in the Asia Pacific countries has tended to exhibit a greater degree of co-movement, but it is fairly very small to call it a complete convergence.

Given that we observe a tendency for greater convergence in the most recent period since 1999, we next investigate whether joining APEC has contributed to it. We repeat our estimation by splitting the sample into two sub-periods: 1971-1989 and 1990-2004. Except for Mexico, which joined APEC in November 1993, all the other countries in our sample joined APEC in November 1989. Figure 5 depicts the t-statistic for the mean correlations, along with 95-percent confidence bands, for the two sub-periods. The t-statistic is computed as $m_{t} / \operatorname{var}\left(m_{t}\right)^{1 / 2}$, where $\operatorname{var}\left(\mathrm{m}_{\mathrm{t}}\right)$ is given by equation (6). According to the linear de-trending and Kalman filter methods, we conclude that the mean correlation coefficient was statistically insignificant for the 19711989 period $^{5}$, indicating, on average, no co-movement in business-cycles of the APEC countries. By contrast, for the second sub-period, the mean correlation coefficient becomes positive and statistically significant from about the end of 2000 and onwards, suggesting business cycle synchronization. Such a finding could be attributed to the APEC, as well as to some common shocks in the region.

3.1.2 Testing for convergence among Australia, Japan and South Korea

\footnotetext{
${ }^{5}$ The wavelet estimate is not computed due to the small number of observations in each sub-period.
} 
Monthly data of Australian industrial production is not available from the IFS after December 1977. Therefore, in order to study the degree of convergence between Australia and some large Asian economies, we resorted to quarterly data, which is available for Japan and South Korea from 1957:3 through 2003:3.

Table 3 reports unit-root tests. Table 4 and Figures 6 and 7 show the convergence results. In this case, the three different trend-cycle decomposition methods yield more homogeneous estimates, especially for some quarters. The mean correlation exhibits an erratic pattern, which is characterized for some periods of relatively large co-movement (late 1980's, according to the three methods and 1995-1996 and 2000-2003 periods, according to the Kalman filter method). As a result, the statistical significance of the mean correlation coefficient sharply fluctuates over the sample period. As Figure 7 shows, the mean correlation was statistically insignificant between the late 1970's and mid-1980's. From 1989 onwards, when it is significant, it is negative, indicating that, on average, business cycles are inversely correlated, suggesting no business cycles convergence.

\subsection{The North American Trade Agreement (NAFTA)}

NAFTA was launched by Canada, Mexico, and the United States in January 1994. Following a final tariff reduction between Canada and Mexico, which took place in January 2003, essentially all trade in the NAFTA region has flowed tariff-free. Since the introduction of NAFTA, both Canada and Mexico have increased their exports to the United States: Canadian manufacturers currently send more than half their production to the U.S., while Mexico's share of the U.S. import market has almost doubled from 6.9 percent in pre-NAFTA 1993 to 11.6 percent in 2002. (Canadian Department of Foreign Affairs and International Trade, www.dfaitmaeci.gc.ca).

Given the data availability from the IFS, we focus on the Mexican industrial, mining, and industrial sectors, the US industrial and petroleum sectors, and the Canadian industrial sector. The sample period covers the period from January 1970 through March 2004. Unit roots for the six production indices are presented in Table 5 . We observe a similar pattern to that reported in Table 1. 
Table 6 and Figures 8 and 9 report our results on convergence. Compared to APEC members analyzed, we observe a higher degree of co-movement among the economic sectors of the NAFTA countries. An interesting finding is that the mean correlation was as high in the early 1980's as in the mid-1990. In other words, the introduction of NAFTA does not seem to have contributed significantly to the convergence, which already was present during the pre-NAFTA period. Notwithstanding, the mean correlation has tended to exhibit an increasing trend from the beginning of 2000 onwards (Figure 8). In this regard, our evidence would be consistent with Torres and Vela (2003)'s.

Scatter plots of $\mathrm{m}_{\mathrm{t}}$ and $\mathrm{v}_{\mathrm{t}}^{2}$ show an inverse relation between the two variables for the linear de-trending and Kalman filter methods (Panels (a) and (c) of Figure 9). Due to some outlier observations, such pattern is less apparent for the wavelet method. On the other hand, the mean correlation is concentrated around relative high values. For instance, the third quartile of the $\mathrm{m}_{\mathrm{t}}$ distribution is located around 0.23 for the three trend-cycle decomposition methods, and around 0.12 for the Harding-Pagan's turning-point procedure (Table 5). These values are substantially higher than those found for the core APEC members in our sample, and for Australia, Japan and South Korea.

\subsection{Asynchronicity in business cycles}

Our previous estimation results show, in general, that convergence is far from complete among APEC and NAFTA members. Therefore, one possibility is that business cycles are asynchronous. In other words, it is possible that the transmission of business cycles from one country to others takes longer than expected. As we argue below, this might be due in part to market rigidities that slow down the transmission of market shocks, or to the fact that sectorspecific shocks affect countries differently due to high economic specialization.

A statistical tool to quantify the degree of business-cycle asynchronicity is the Spearman's rank correlation. This is a non-parametric method that measures the correlation between two variables $\mathrm{X}$ and $\mathrm{Y}$, and it is defined as

$$
\rho_{\mathrm{s}}=1-6\left(\frac{\sum \mathrm{d}_{\mathrm{i}}^{2}}{\mathrm{M}\left(\mathrm{M}^{2}-1\right)}\right)
$$


where $d_{i}$ is the difference in the ranks assigned to the corresponding values of two series $X$ and $\mathrm{Y}$, where $\mathrm{M}$ is the number of $(\mathrm{X}, \mathrm{Y})$ pairs in the sample. Like the Pearson correlation coefficient, the rank correlation takes on values between -1 and 1 .

Under the null hypothesis that the populations rank correlation is zero and for $\mathrm{M}>8$, the significance of the sample $r_{s}$ can be contrasted using a t-test:

$$
\mathrm{t}=\frac{\mathrm{r}_{\mathrm{s}} \sqrt{\mathrm{M}-2}}{\sqrt{1-\mathrm{r}_{\mathrm{s}}^{2}}} \sim \mathrm{t}(\mathrm{M}-2)
$$

Figure 10 and Table 7 and show these results. We use a rolling-window of 7 years for the linear de-trending, wavelet, and Kalman filters, and a rolling window of 14 years for the Harding-Pagan procedure. The lag between observations of business-cycle industrial production is 2 years. Panels (a) through (c) of Figure 10 show the evolution of the Spearman rank correlation and of the t-test for the null hypothesis of zero correlation against the alternative of positive correlation. Overall, in Panels (a) and (c) we reject the null hypothesis of zero correlation. The evolution of the t-test for Panel (b) is rather erratic. Over some time periods, we find a statistically insignificant correlation between lagged business cycles. This supports our previous results on the lack of convergence among Australia, Japan and South Korea's business cycles.

The results in Table 7 are interesting. When we take observations distant in time, the distributions of the three trend-cycle decomposition methods and the Harding-Pagan procedure are more homogeneous than in the case when we compute the correlation coefficients with contemporaneous observations of the business cycles (see Tables 2 and 4). In addition, the correlation coefficients are much larger, averaging around 0.3. These findings confirm our conjecture that business-cycles transmission does not occur rapidly. These results are also in line with Selover (1999)'s conclusions for ASEAN countries.

To summarize, we conclude that business cycles convergence has not been achieved among APEC and NAFTA countries. Instead, we find that business-cycles became more asynchronous over time. This can be explained by several reasons. First, it is possible that large domestic shocks dominate relatively small international shocks. Second, due to trading arrangements, as trade became more integrated, countries specialized more in different sectors, which reduced the international correlation of business cycles because of the different sector- 
specific shocks affecting countries differently (Eichengreen, 1992; Krugman, 1993). Third, demand or supply shocks in one country transmit slowly to others. This last argument goes against the argument made by Frankel and Rose (1998) that trade arrangements make the productive sectors of countries more dependent upon each other and, hence, shocks facing a country are transmitted quickly to other countries, causing synchronization of business cycles. Our empirical results are more in line with the arguments made in Eichengreen (1992) and Krugman (1993) in that trading arrangements increase the degree of specialization in individual member countries.

\section{Conclusion}

Our study analyzes whether convergence has taken place among different Asia-Pacific and NAFTA countries. We apply different techniques to identify business cycles. In particular, the novelty of our study is using wavelet methods for such purpose. Our estimation results show that the convergence of business cycles of the Asia-Pacific countries is still far from being achieved. However, after joining the APEC, the mean correlation of industrial production cycles of member economies has tended to increase. On the other hand, some economic sectors of the US, Mexico, and Canada exhibited a relative degree of co-movement even before launching the NAFTA. Introduction of the NAFTA has not significantly increased the already existing business cycles synchronization in the region. The finding suggests that regional trading arrangements do not necessarily increase business cycles synchronization, but trade flows itself does. On the other hand, our empirical results support the theoretical arguments that regional trade arrangements tend to increase specialization in individual member countries.

In addition, we find evidence that the transmission of business cycles among APEC or NAFTA members is relatively slow, and, hence, the mean correlation of business cycles increases when taking observations apart in time. In other words, business cycles are asynchronous. 


\section{References}

Artis, M., and W. Zang (1997), "International business cycles and the ERM: is there a European business cycle?” International Journal of Finance and Economics 2, 1-16.

ERM: is there a European business cycle?” Oxford Economic Papers 51, 120-132.

Babetskii, I. (2005), “Trade Integration and Synchronization of Shocks: Implications for EMU Enlargement.” Economics of Transition 13(1), 105-138.

Baxter, M., and R. King (1999), "Measuring Business Cycles: Approximate Band-Pass Filters for Economic Time Series”. The Review of Economics and Statistics 81(4), 575-593.

Blanchard, O., and D. Quah (1989), “The dynamic effects of aggregate demand and supply disturbances.” American Economic Review 79(4), 655-673.

Bruce A. and H. Gao (1996), Applied Wavelet Analysis with S-Plus. Springer-Verlag.

Canova, F. (1998), "Detrending and business cycles facts.” Journal of Monetary Economics 41(3), 475-512.

Eichgreen, B. (1992), “Should the Maastricht Treaty be saved?” Princeton Studies in International Finance 74, New Jersey: Princeton University.

Fidrmuc, J., and I. Korhonen (2004), “A meta-analysis of business cycle correlation between the Euro area and CEECs: What do we know-and who cares?” Mimeo, Oesterreichische National Bank, Austria, and Institute for Economies in Transition, Bank of Finland.

Frankel, J. and A. K. Rose (1998), "The endogeinity of the optimum currency area." The Economic Journal 108 (449), 1009-1025.

Frankel, J. (2004), "Real Convergence and Euro Adoption in Central and Eastern Europe: Trade and Business Cycle Correlations as Endogenous Criteria for Joining EMU.” KSG Faculty Research Working Papers RWP04-039. Harvard University.

Gençay R., B. Whitcher, and F. Selçuk (2001), "Differentiating Intraday Seasonalities through Wavelet Multi-Scaling.” Physica A, 289, 543-556.

(2002). An Introduction to Wavelets and Other Filtering Methods in Finance and Economics. Academic Press, San Diego.

Quantitative Finance 3, 108-116. (2003), “Systematic Risk and Time Scales." (2004), “Multiscale Systematic Risk.” Journal of International Money and Finance 23 (forthcoming).

Harding, D. and A. Pagan (2001), "Extracting, analyzing and using cyclical information." Mimeo, University of Melbourne. 
Hong, Y., and C. Kao (2004), "Wavelet-Based Testing for Serial Correlation of Unknown Form in Panel Models.” Econometrica 72(5), 1519-1563.

Krugman, P. (1993), “Lessons of Massachusetts fro EMU.” In F. Giavazzi and F. Torres (eds.) The Transition to Economic and Monetary Union in Europe. Cambridge: Cambridge University Press, 241-261.

Mundell, R. (1961), “A theory of optimum currency areas.” American Economic Review 51, 657-665.

Lin, Shinn-Juh and M. Stevenson (2001), "Wavelet Analysis of the Cost-of-Carry Model." Studies in Nonlinear Dynamics \& Econometrics 5(1), 87-102.

Massmann, M. and J. Mitchell (2003), "Reconsidering the evidence: Are Eurozone business cycles converging?” Center for European Integration Studies, Rheinische Friedrich-WilhelmsUniversität Bonn. Working paper B-05 2003.

Percival, D., and A. Walden (2000), Wavelets Analysis for Time Series Analysis. Cambridge University Press, Cambridge, U.K.

Ramsey J., and C. Lampart (1998), “The Decomposition of Economic Relationships by Time Scale Using Wavelets: Expenditure and Income." Studies in Nonlinear Dynamics \& Econometrics 3(1), 23-42.

Ramsey, J. (1999), "The Contribution of Wavelets to the Analysis of Economic and Financial Data.” Phil. Trans. R. Soc. Lond. A, 357, 2593-260.

(2002), "Wavelets in Economics and Finance: Past and Future." Studies in Nonlinear Dynamics \& Econometrics 6(3), 1-29.

Selover, D. (1999), "International Interdependence and Business Cycle Transmission in ASEAN,” Journal of the Japanese and International Economies 13, 230-253.

Shin, K., and Y. Wang (2004), "Trade integration and business cycle co-movements: the case of Korea with other Asian countries,” Japan and the World Economy 16, 213-230.

Torres, A, and O. Vela (2003), "Trade integration and synchronization between the business cycles of Mexico and the United States,” North American Journal of Economics and Finance 14, 319-342.

Whitcher, B. (2004). "Wavelet-Based Estimation for Seasonal Long-Memory Processes." Technometrics 46 (2), 225-238.

Zivot, E., \& J. Wang (2003), Modeling Financial Times Series with S-Plus. Insightful Corporation. 


\section{FIGURES}

Figure 1 Japanese industrial production index

(a) Multi-resolution decomposition

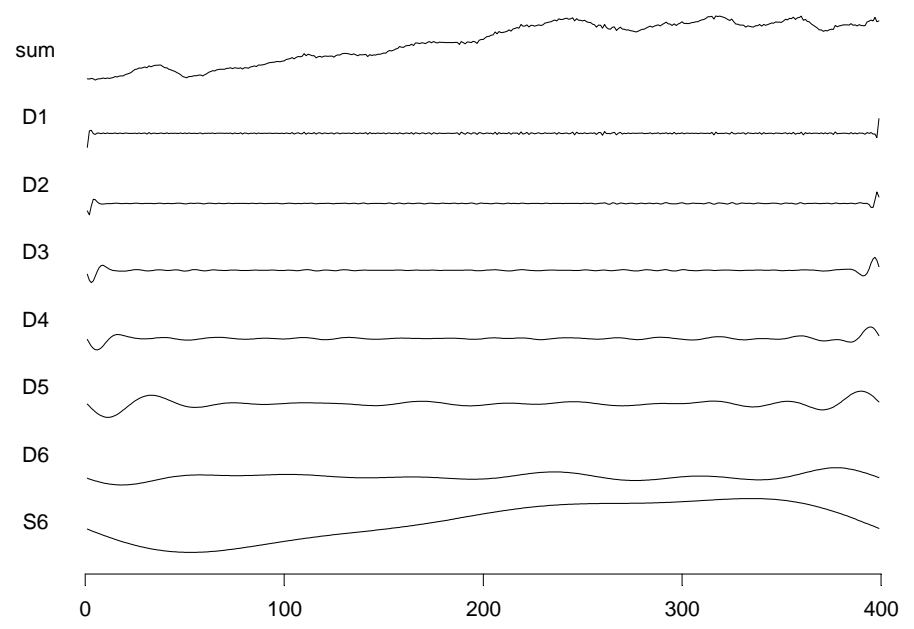

(b) Trend and business-cycle decomposition
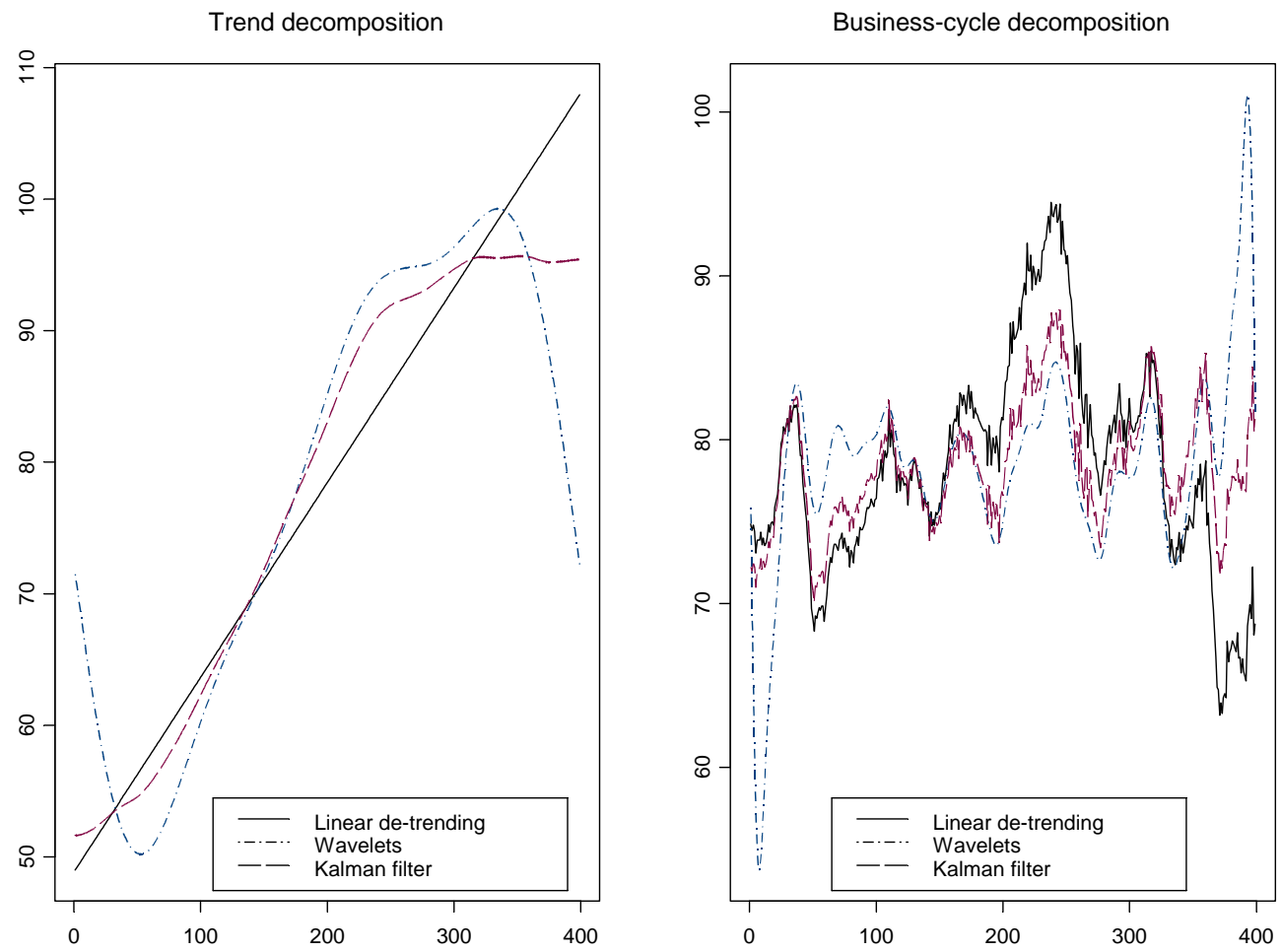
Figure 2 GMM estimates of $m_{t}$ and $v_{t}^{2}$ of core APEC countries
(a) Linear de-trending
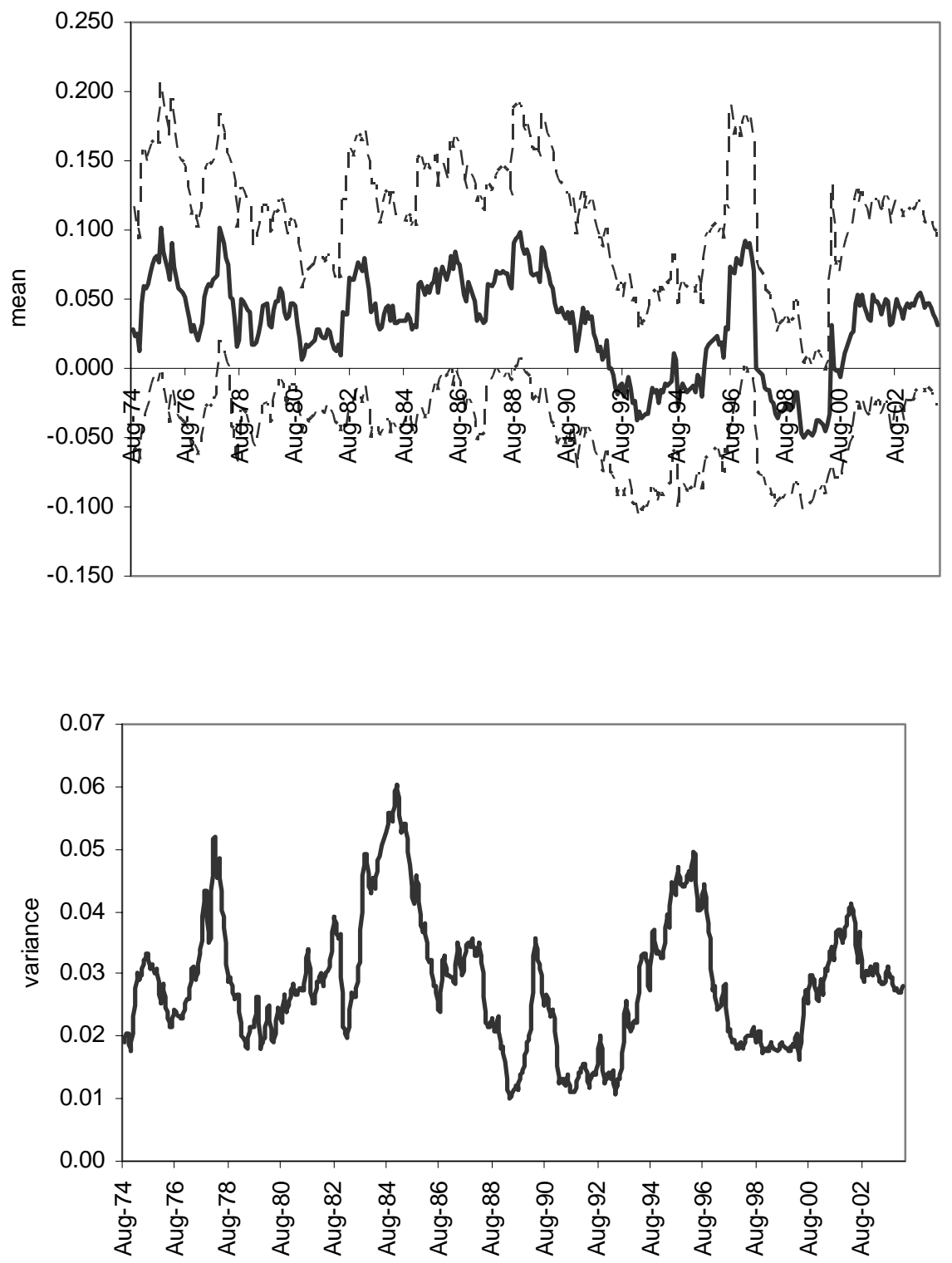
(b) Wavelet method
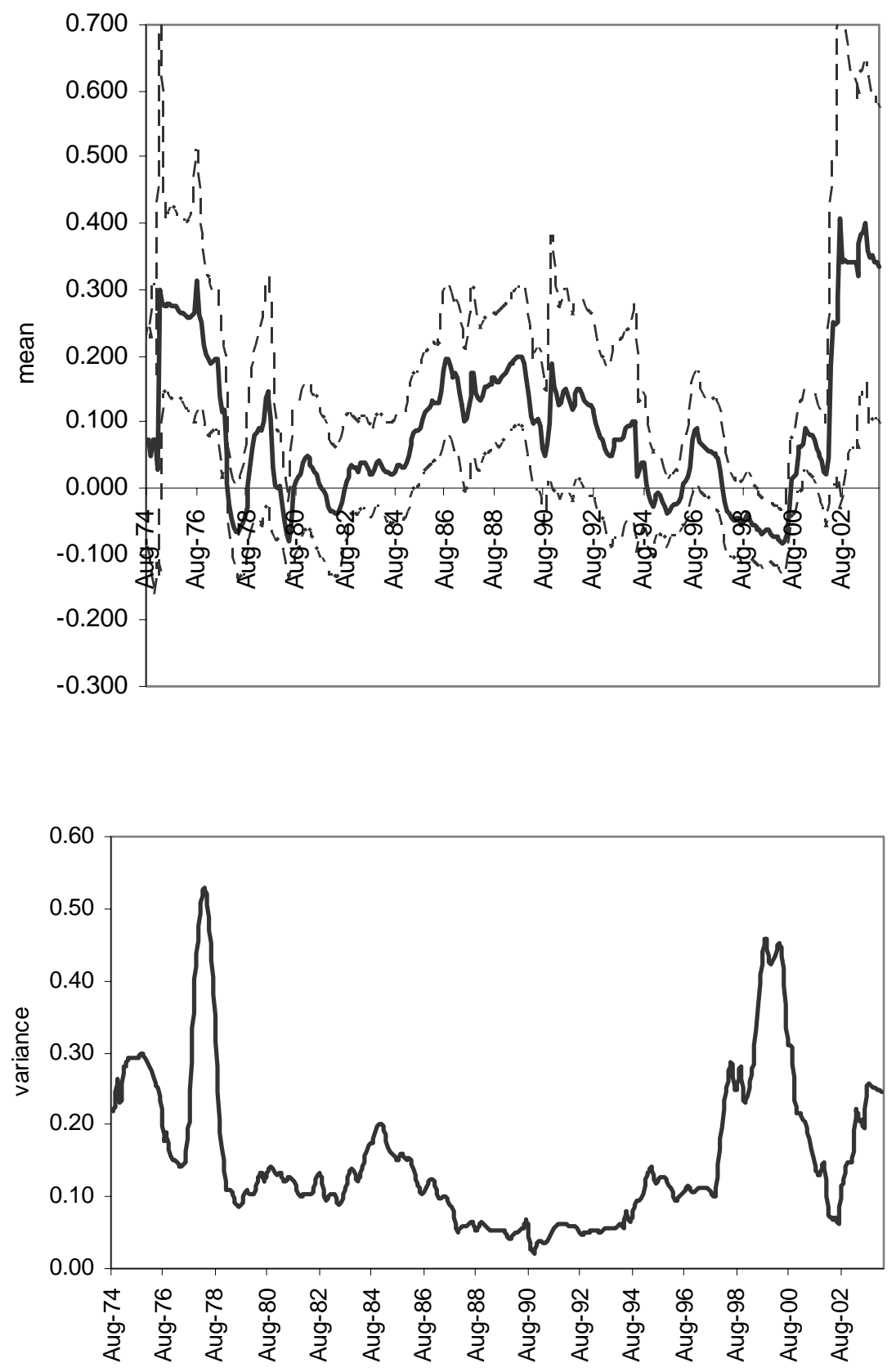
(c) Kalman filter
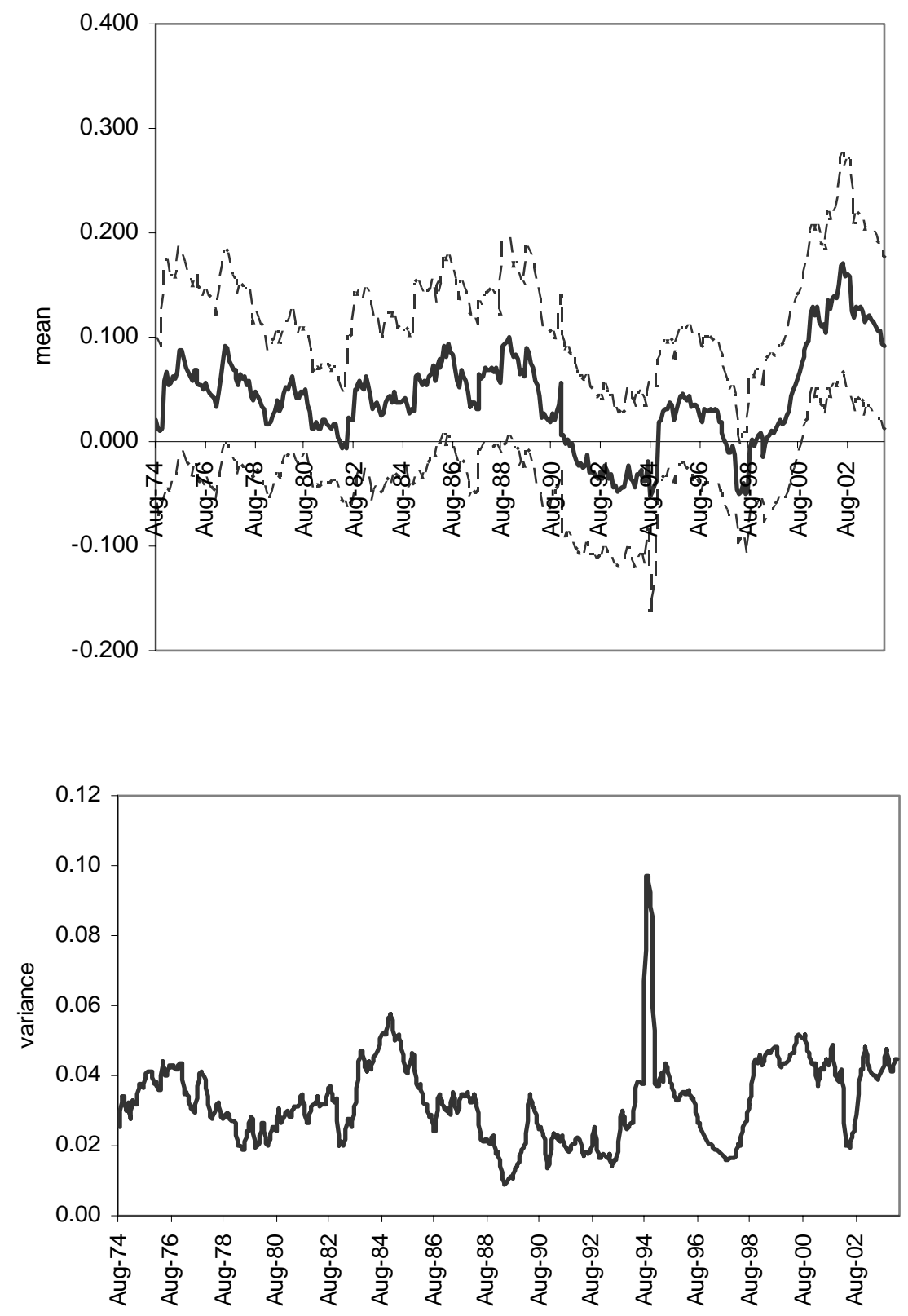

Notes: (1) Dashed lines indicate 95-percent confidence intervals estimated by the generalized method of moments (GMM). (2) The rolling window is of 3.5 years. (2) The countries considered are Japan, South Korea, Malaysia, Mexico, USA, and Canada. 
Figure 3 Relation between $\mathrm{m}_{\mathrm{t}}$ and $\mathrm{v}_{\mathrm{t}}^{2}$ for core APEC countries

(a) Linear de-trending method

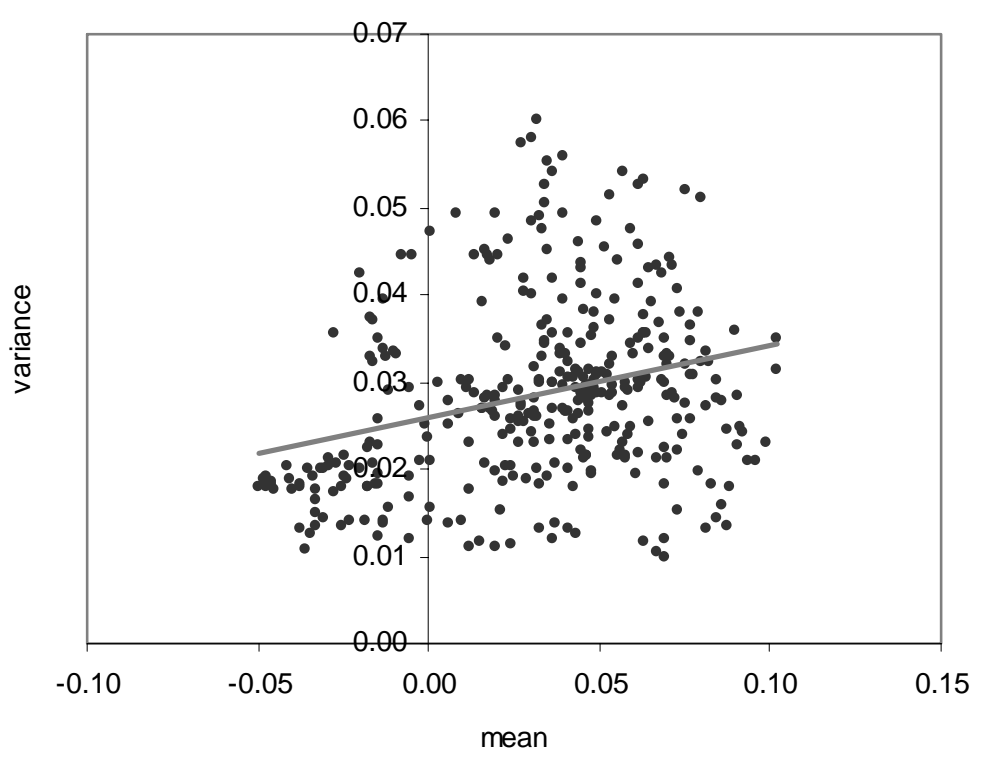

(b) Wavelet method

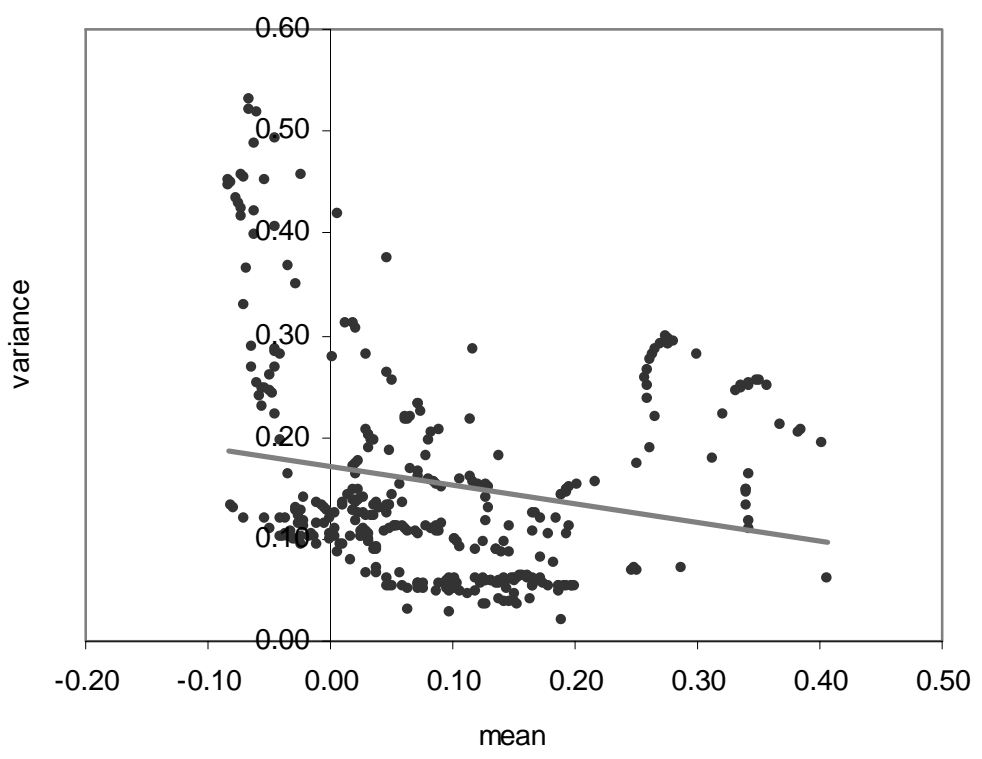


(c) Kalman filter

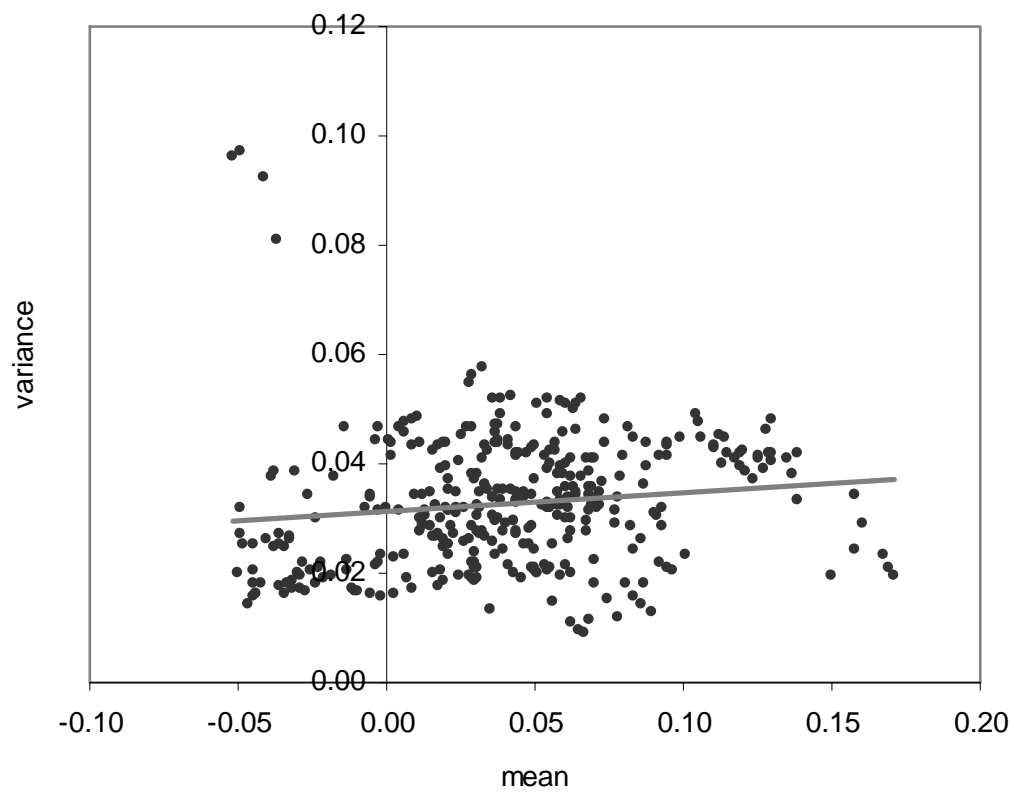

Note: The countries considered are Japan, South Korea, Malaysia, Mexico, USA, and Canada. 
Figure 4 Mean estimates of APEC countries relative to Harding-Pagan's turning points

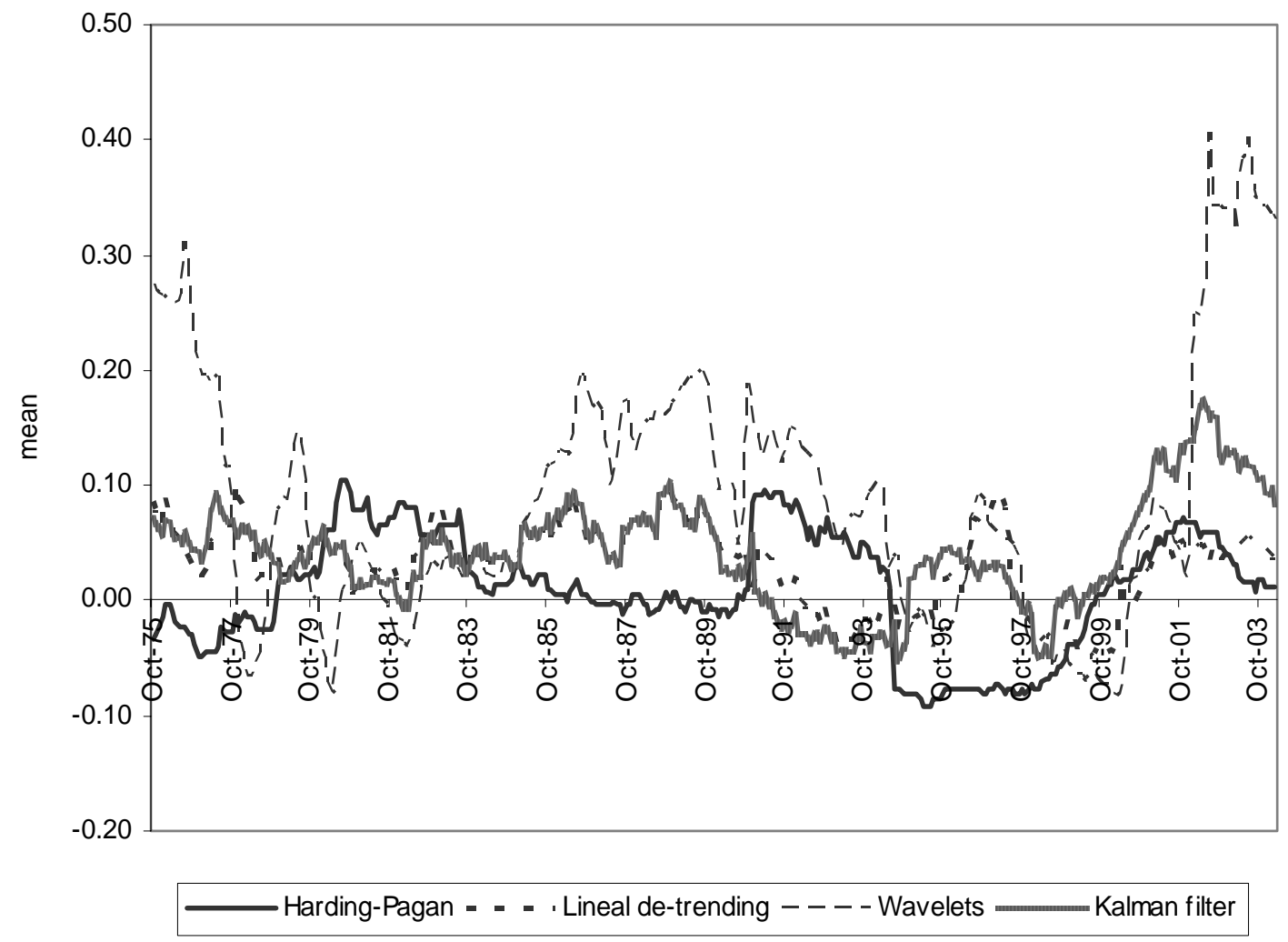

Note: The countries considered are Japan, South Korea, Malaysia, Mexico, USA, and Canada.

Figure $5 \quad$ T-statistic for $m_{t}$ of APEC countries

(a) Prior to 1990

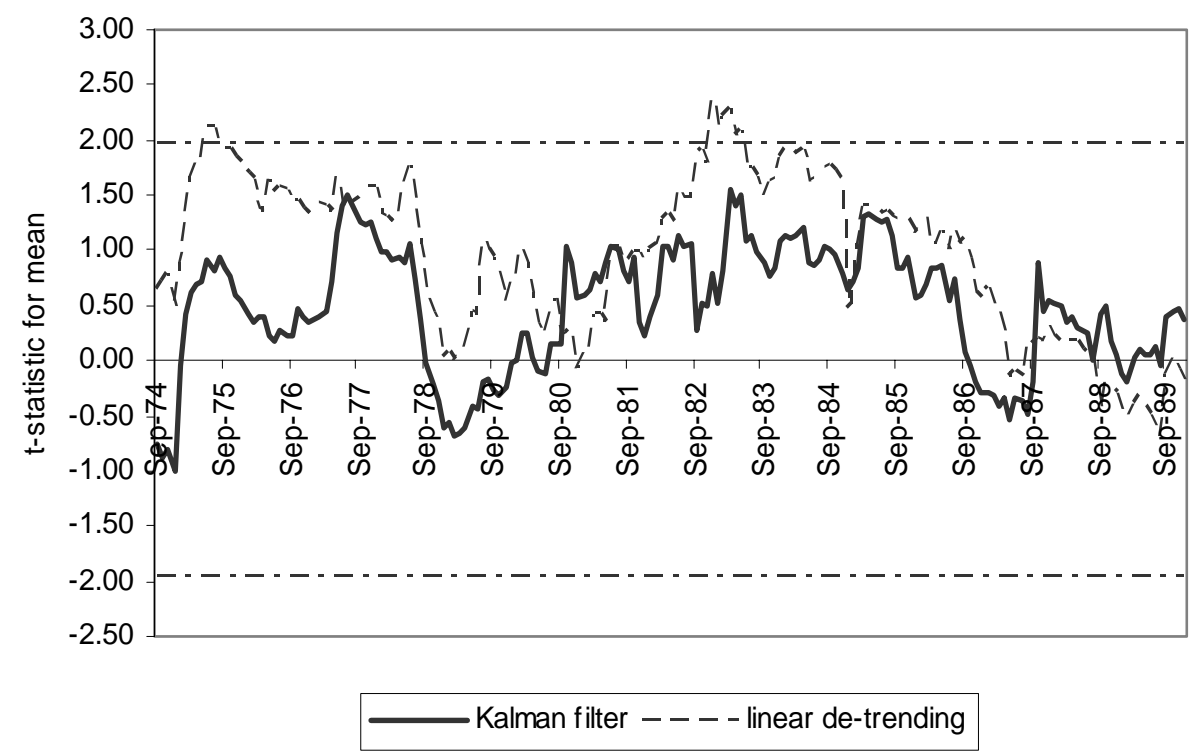


(b) From 1990 onwards

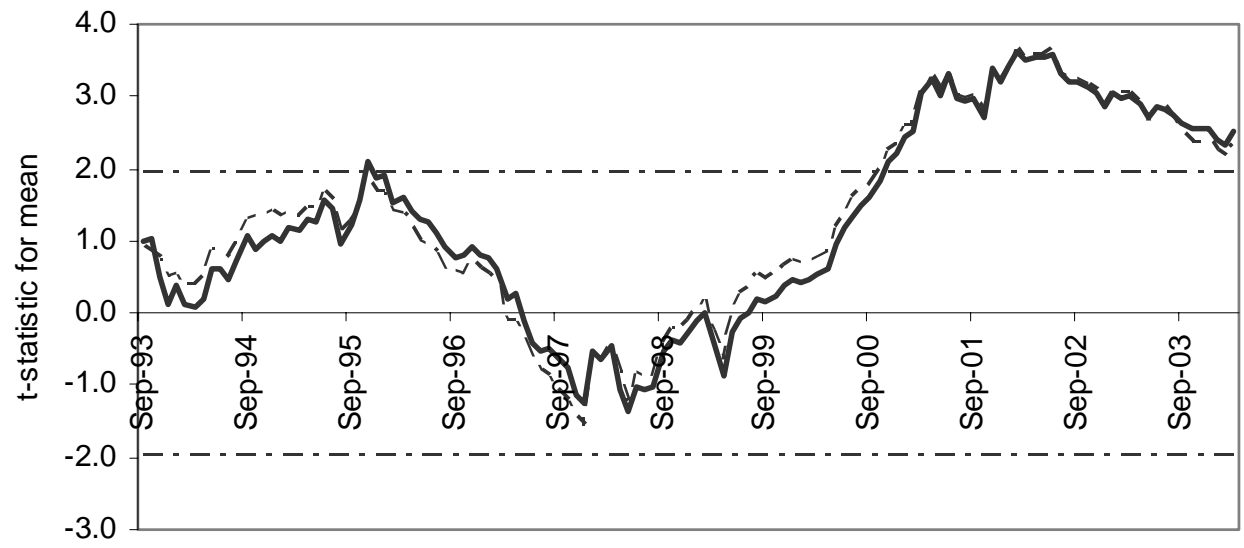

Kalman filter - - - - linear de-trending

Note: (1) The horizontal dashed lines represent 95-percent confidence bands. (2)_The countries considered are Japan, South Korea, Malaysia, Mexico, USA, and Canada.

Figure 6 GMM estimates of $\mathrm{m}_{\mathrm{t}}$ for the Australian, Japanese and South Korean industrial sectors

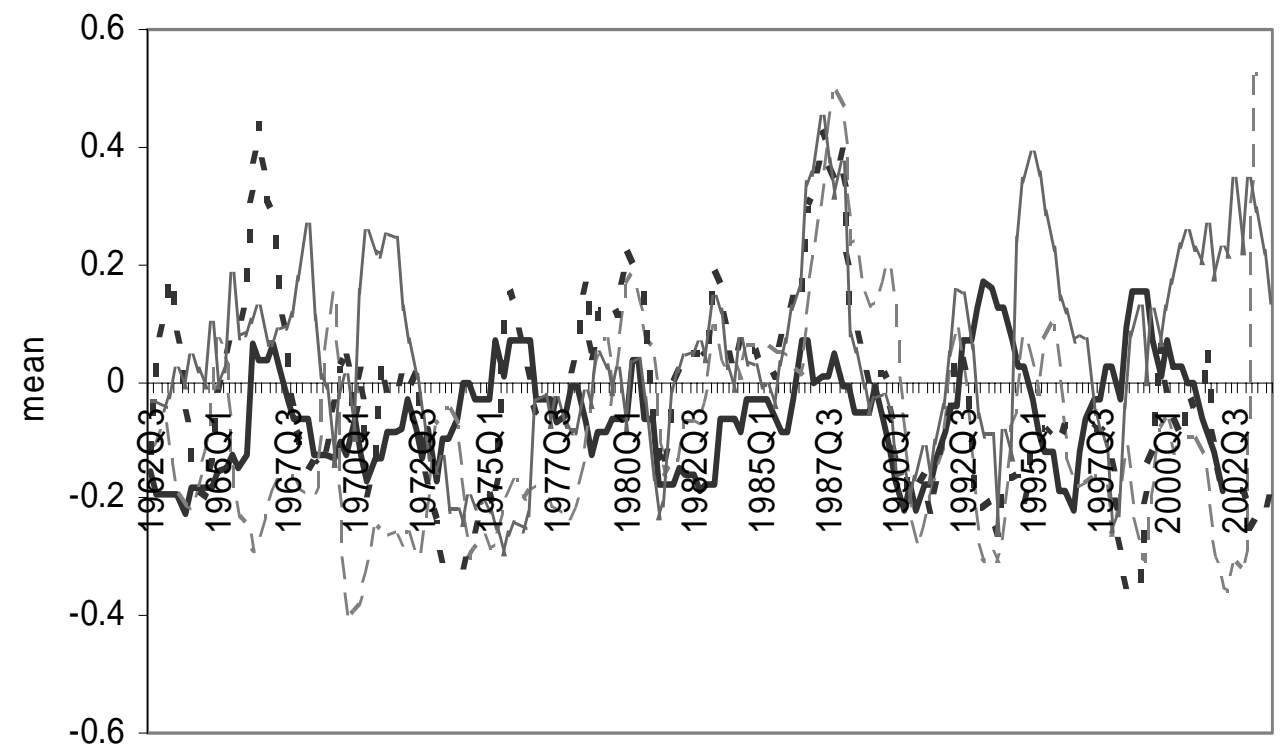

Harding Pagan - - - - Wavelets - - - ' Linear de-trending

Kalman filter 
Figure $7 \quad$ T-statistic for $m_{t}$ for the Australian, Japanese and South Korean industrial sectors

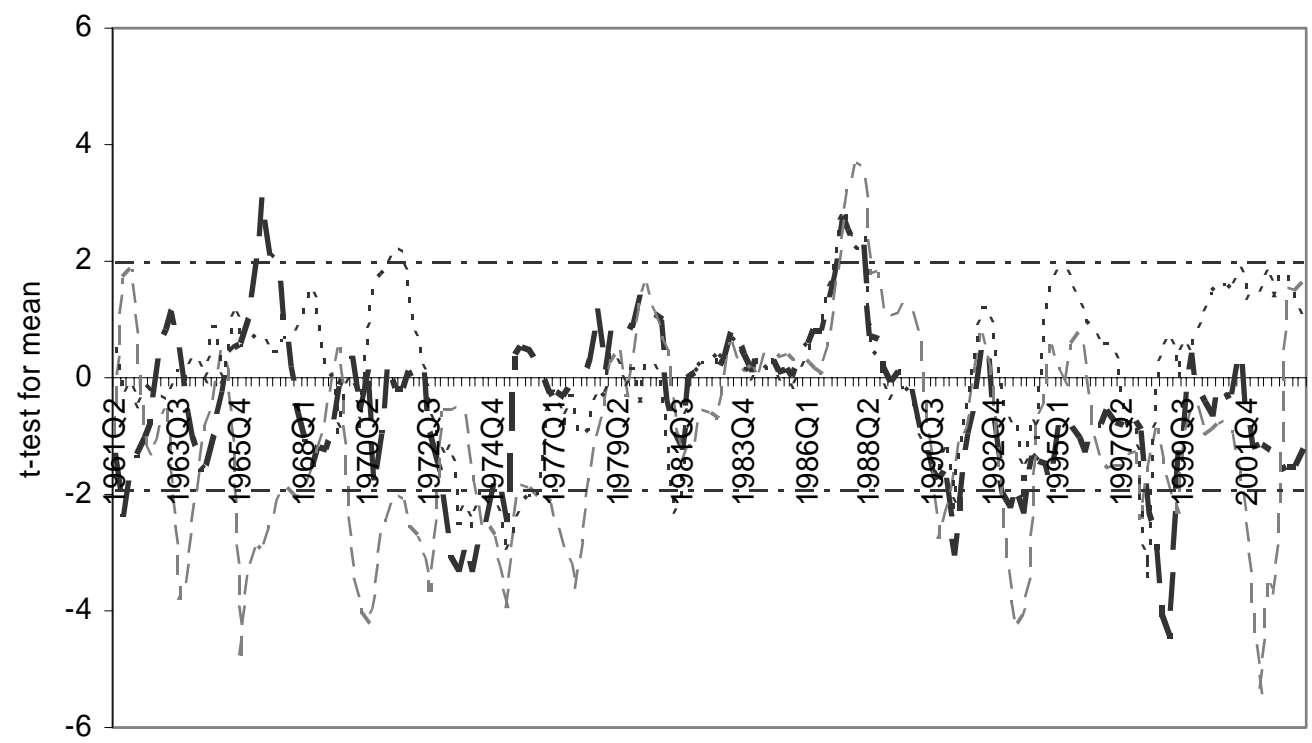

- - linear de-trending - - - Wavelets ...... Kalman

Figure $8 \quad$ GMM estimates of $m_{t}$ for NAFTA countries

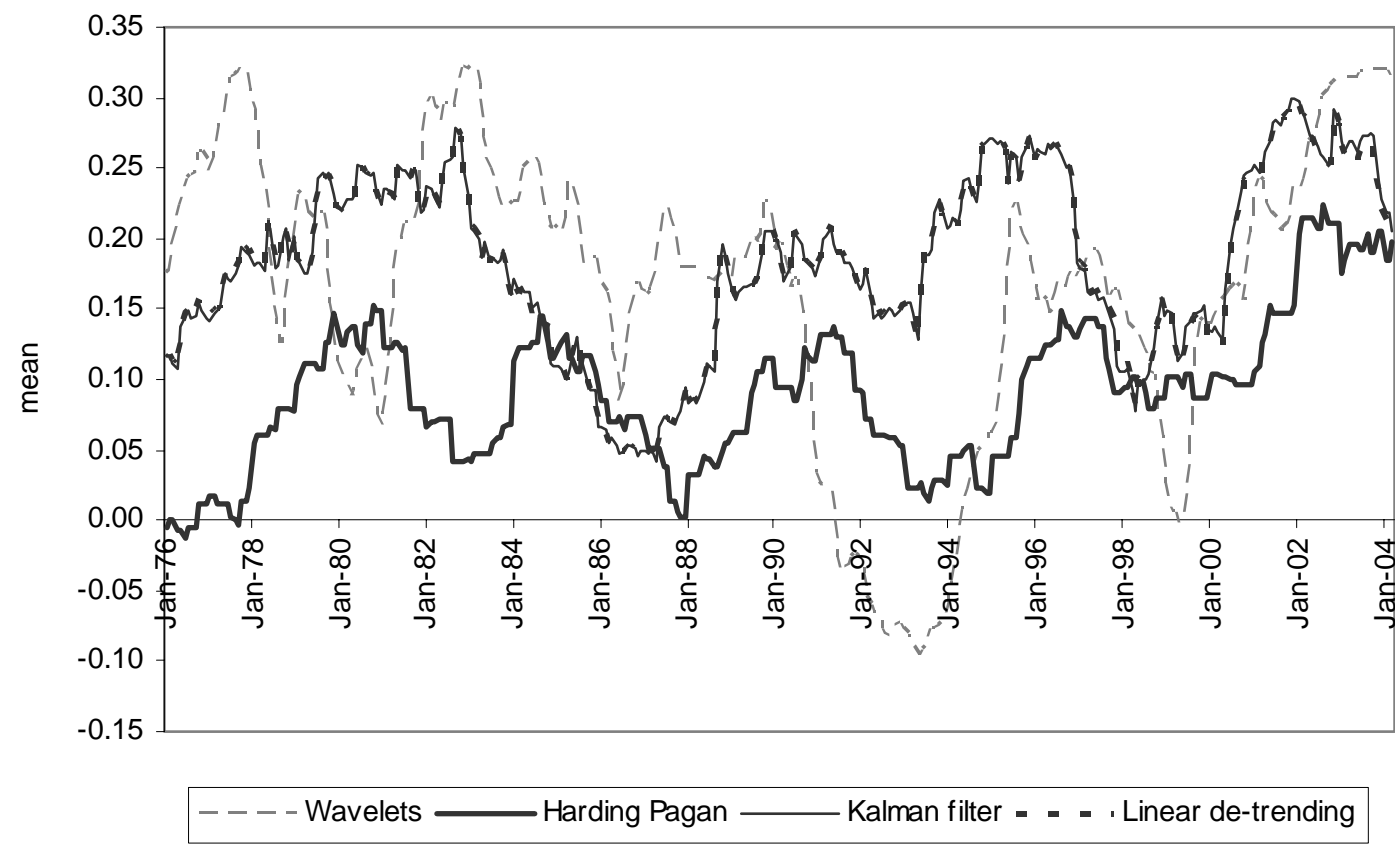

Note: The indices include the Mexican mining, manufacturing, and industrial production sectors, the US industrial and crude petroleum production sectors indices and the Canadian industrial production sector. 
Figure 9 Relation between $m_{t}$ and $v_{t}^{2}$ for NAFTA countries

(a) Linear de-trending method

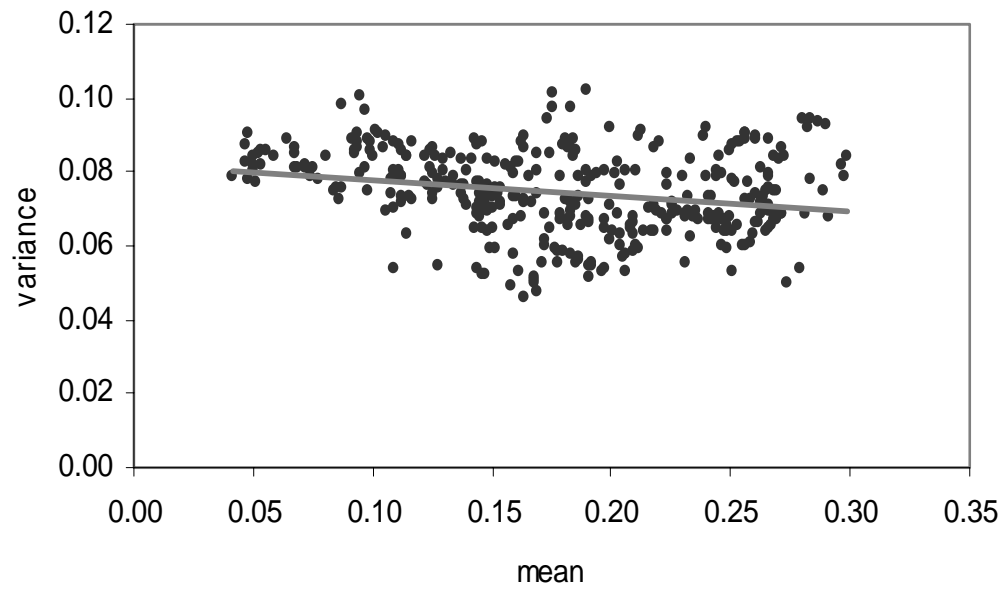

(b) Wavelet method

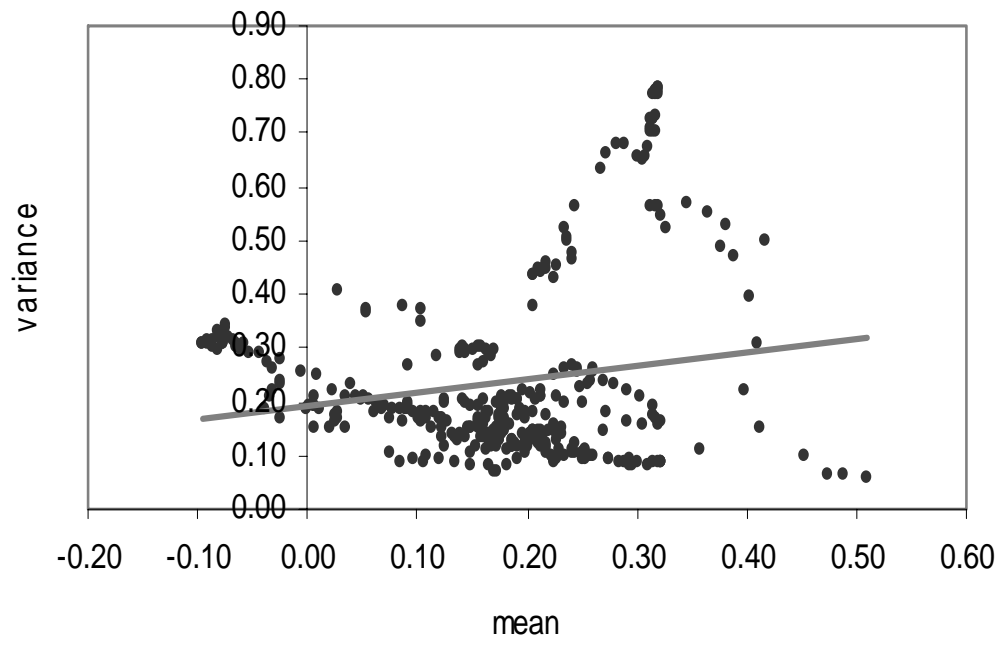


(c) Kalman filter

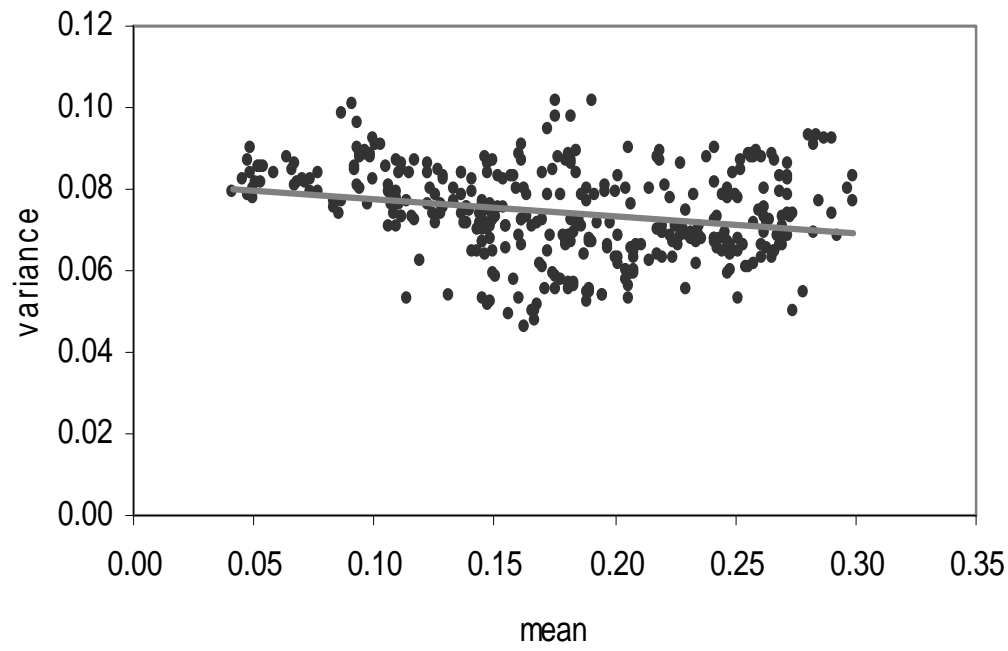

Note: The indices include the Mexican mining, manufacturing, and industrial production sectors, the US industrial and crude petroleum production sectors indices and the Canadian industrial production sector. 
Figure $10 \quad$ Persistence in convergence

(a) Core sampled APEC countries

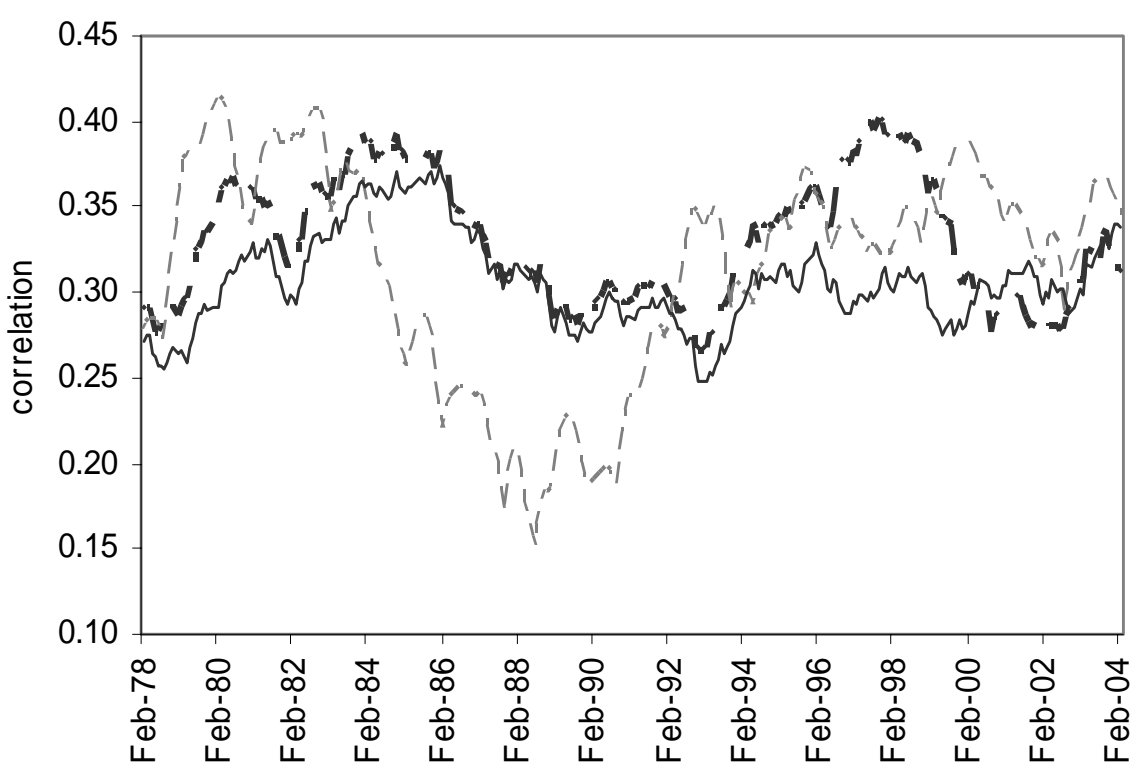

- — Linear de-trending - - - - w avelets _ Kalman filter

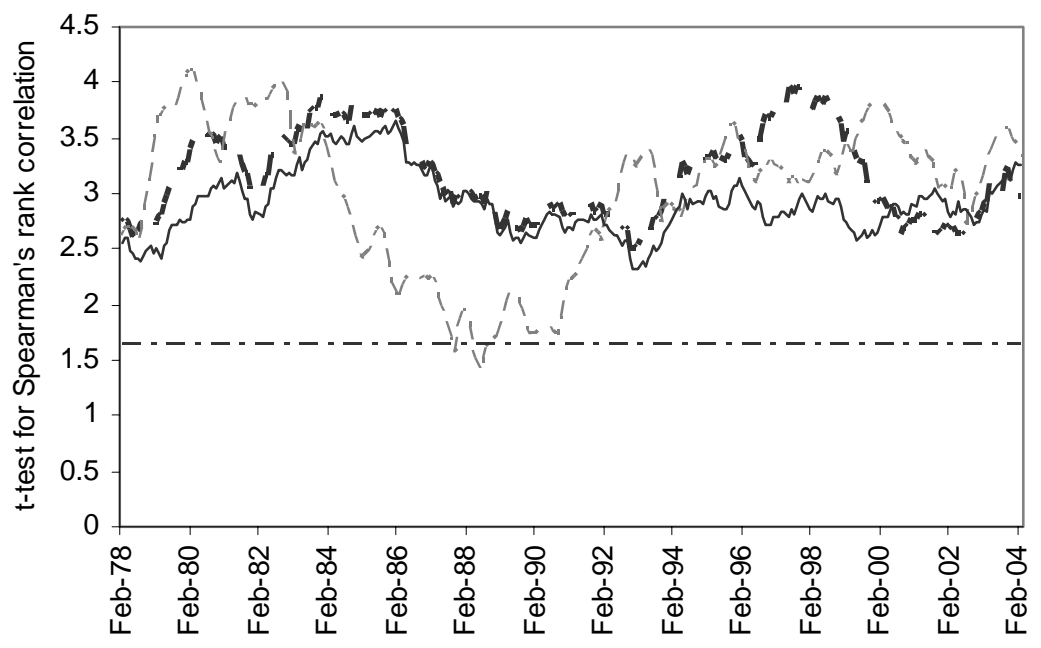

- - Linear de-trending ---- w avelets _ Kalman filter 
(b) Australia, Japan and South Korea

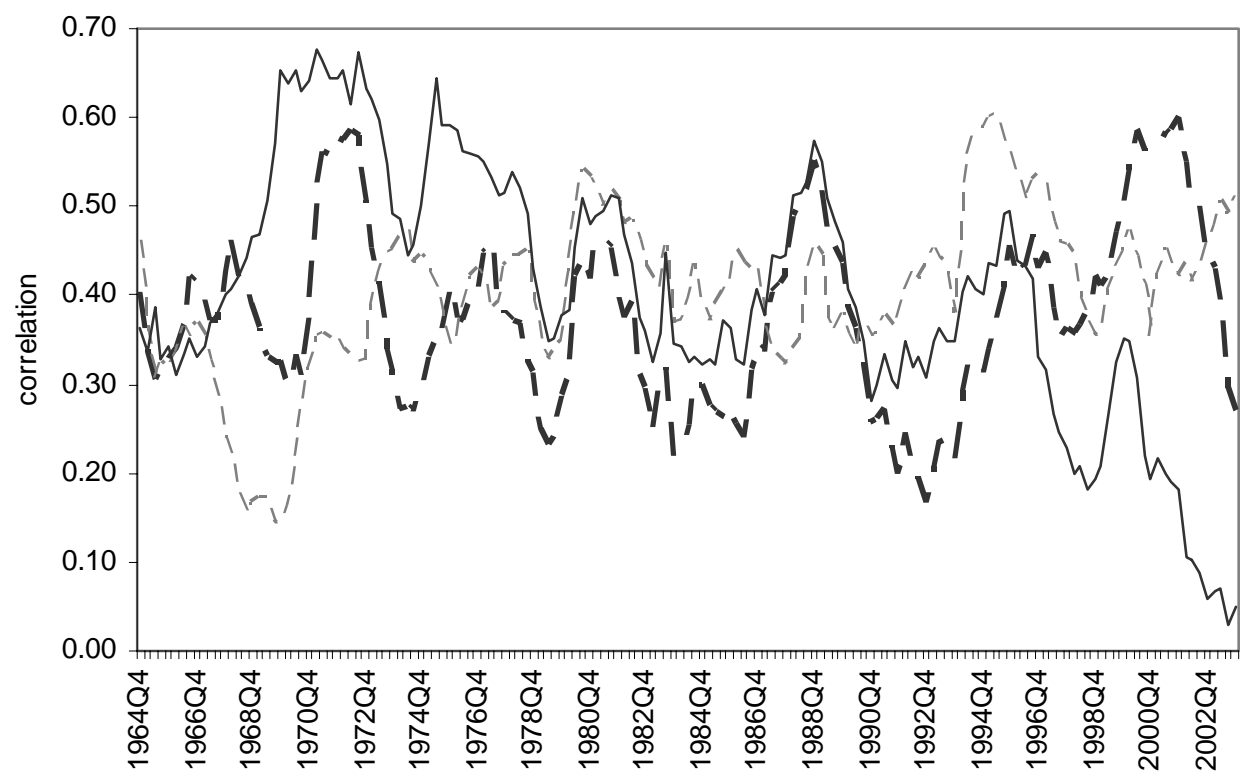

- - Linear de-trending ---- w avelets __ Kalman filter

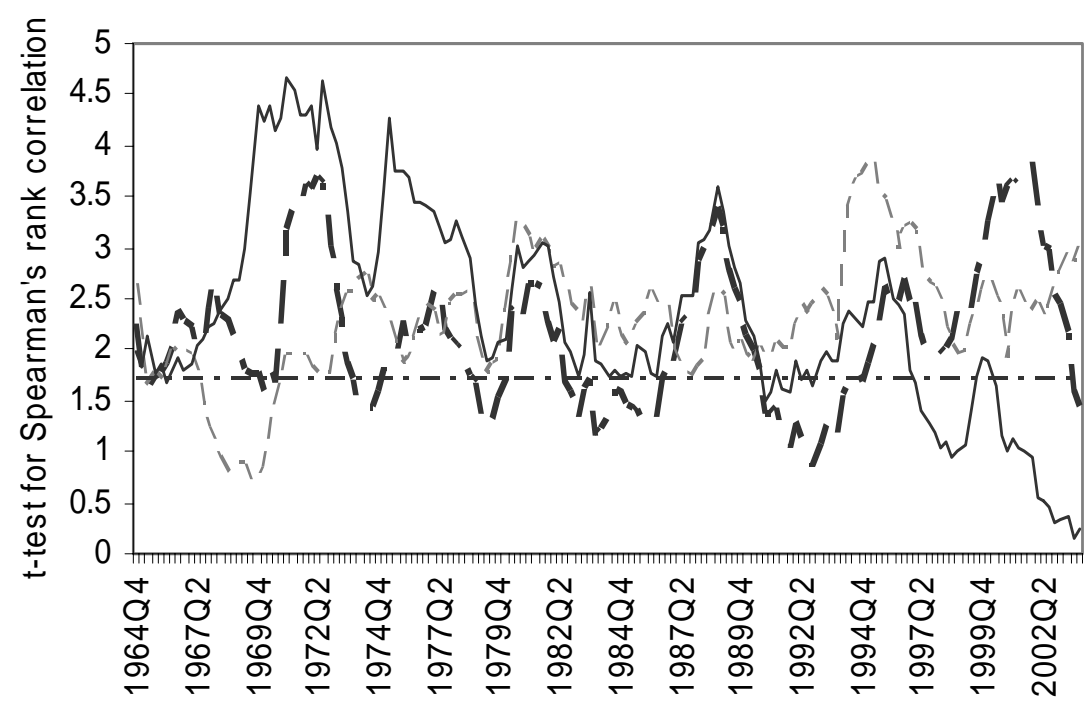

- — Linear de-trending - - - - w avelets _Kalman filter 
(c) NAFTA countries
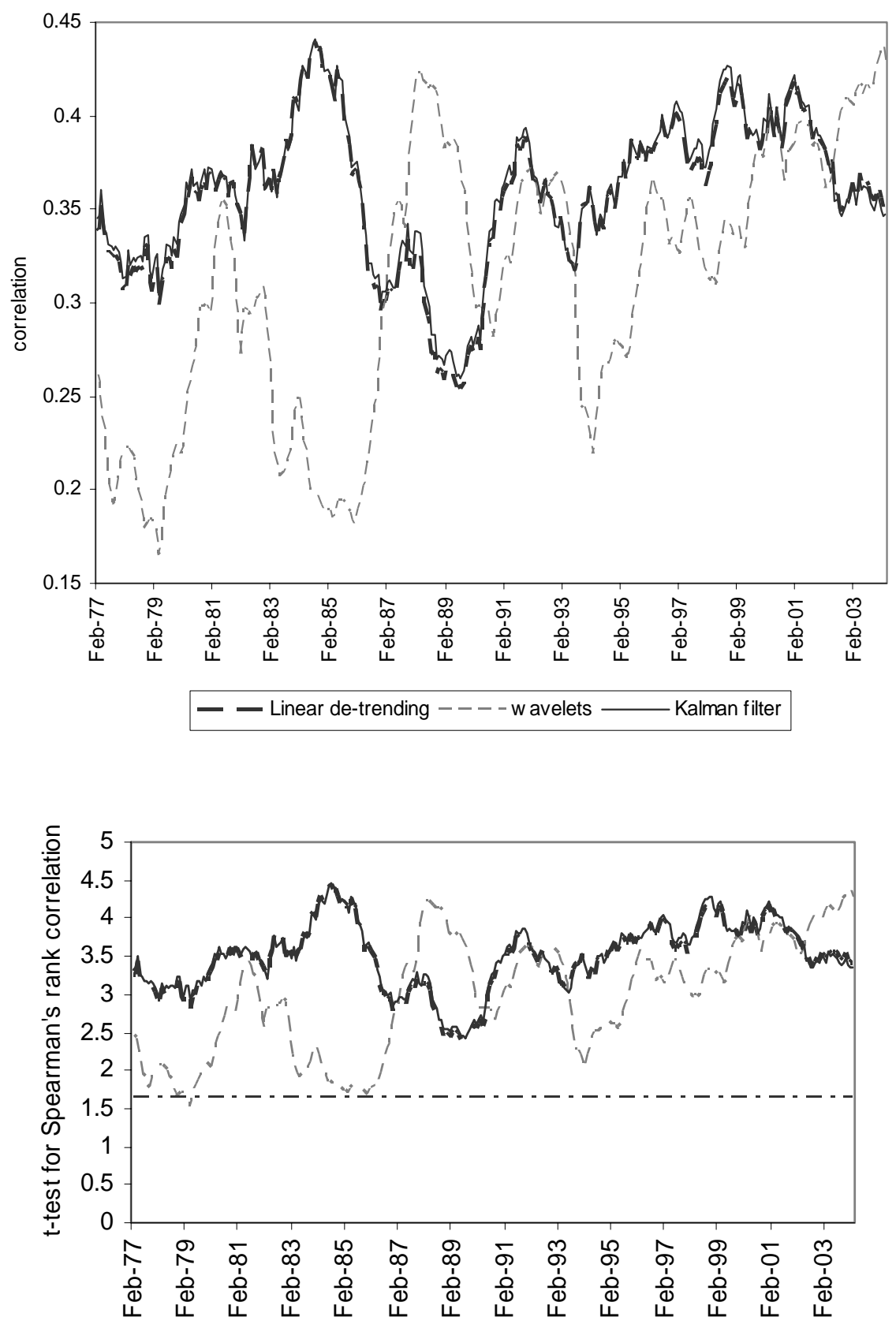

- - Linear de-trending ---- w avelets _ Kalman filter

Notes: (1) In Panels (a)-(c), we use a rolling-window of 7 years for the linear de-trending, wavelet, and Kalman filter methods, and a rolling window of 14 years for the Harding-Pagan procedure. The lag between observations is 2 years. The sample periods for Panels (a)-(c) are April 1986-March 2004, 1973:1-2003:4, and April 1985-March 2004, respectively. (2) For the t-test graphs in Panels (a)-(c), the dashed line indicates the critical value for rejecting the null hypothesis of zero correlation against the alternative of positive correlation. If the t-statistic is above the dotted line, we reject the null hypothesis in favor of the alternative. 


\section{TABLES}

Table 1 Unit-root tests for core APEC countries in the sample

(a) Level and log-level of industrial production indices

\begin{tabular}{ccccccccccccc}
\hline & \multicolumn{2}{c}{ Japan } & \multicolumn{2}{c}{ South Korea } & \multicolumn{2}{c}{ Malaysia } & \multicolumn{2}{c}{ Mexico } & \multicolumn{2}{c}{ United States } & \multicolumn{2}{c}{ Canada } \\
& $\mathrm{X}_{\mathrm{t}}$ & $\log \left(\mathrm{X}_{\mathrm{t}}\right)$ & $\mathrm{X}_{\mathrm{t}}$ & $\log \left(\mathrm{X}_{\mathrm{t}}\right)$ & $\mathrm{X}_{\mathrm{t}}$ & $\log \left(\mathrm{X}_{\mathrm{t}}\right)$ & $\mathrm{X}_{\mathrm{t}}$ & $\log \left(\mathrm{X}_{\mathrm{t}}\right)$ & $\mathrm{X}_{\mathrm{t}}$ & $\log \left(\mathrm{X}_{\mathrm{t}}\right)$ & $\mathrm{X}_{\mathrm{t}}$ & $\log \left(\mathrm{X}_{\mathrm{t}}\right)$ \\
\hline ADF test & -2.13 & -2.26 & 0.20 & -1.79 & -1.57 & -3.61 & -3.06 & -3.17 & -1.81 & -2.94 & -1.39 & -2.35 \\
P-value & 0.59 & 0.51 & 0.99 & 0.78 & 0.86 & 0.03 & 0.11 & 0.09 & 0.76 & 0.14 & 0.91 & 0.45 \\
Lag & 4 & 4 & 1 & 1 & 1 & 1 & 13 & 13 & 15 & 14 & 1 & 1 \\
Min SC & 3.01 & -5.76 & 3.07 & -4.75 & 4.82 & -2.82 & 4.68 & -3.63 & 2.44 & -5.86 & 2.49 & -5.85 \\
\hline
\end{tabular}

(b) First difference and log-first difference industrial production indices

\begin{tabular}{ccccccccccccc}
\hline & \multicolumn{2}{c}{ Japan } & \multicolumn{2}{c}{ South Korea } & \multicolumn{2}{c}{ Malaysia } & \multicolumn{2}{c}{ Mexico } & \multicolumn{2}{c}{ United States } & \multicolumn{2}{c}{ Canada } \\
& $\Delta \mathrm{X}_{\mathrm{t}}$ & $\log \left(\Delta \mathrm{X}_{\mathrm{t}}\right)$ & $\Delta \mathrm{X}_{\mathrm{t}}$ & $\log \left(\Delta \mathrm{X}_{\mathrm{t}}\right)$ & $\Delta \mathrm{X}_{\mathrm{t}}$ & $\log \left(\Delta \mathrm{X}_{\mathrm{t}}\right)$ & $\Delta \mathrm{X}_{\mathrm{t}}$ & $\log \left(\Delta \mathrm{X}_{\mathrm{t}}\right)$ & $\Delta \mathrm{X}_{\mathrm{t}}$ & $\log \left(\Delta \mathrm{X}_{\mathrm{t}}\right)$ & $\Delta \mathrm{X}_{\mathrm{t}}$ & $\log \left(\Delta \mathrm{X}_{\mathrm{t}}\right)$ \\
\hline ADF test & -6.25 & -6.09 & -12.9 & -14.1 & -4.5 & -17.8 & -4.4 & -4.5 & -5.0 & -4.7 & -13.3 & -13.4 \\
P-value & 0.00 & 0.00 & 0.00 & 0.00 & 0.00 & 0.00 & 0.00 & 0.00 & 0.00 & 0.00 & 0.00 & 0.00 \\
Lag & 3 & 3 & 1 & 1 & 11 & 1 & 12 & 12 & 14 & 13 & 1 & 1 \\
Min SC & 2.96 & -5.81 & 3.07 & -4.75 & 4.78 & -2.82 & 4.64 & -3.67 & 2.39 & -5.9 & 2.46 & -5.87 \\
\hline
\end{tabular}

Note: (1) ADF and SC stand for Augmented Dickey-Fuller test and Schwartz criterion, respectively. The lag-order for carrying out the ADF test is determined by minimizing SC. The sample period is January 1971-March 2004.

Table 2 GMM estimates of $m_{t}$ and $v_{t}^{2}$ for core APEC countries in the sample

\begin{tabular}{ccccccccc} 
& \multicolumn{2}{c}{ Linear de-trending } & \multicolumn{2}{c}{ Wavelets } & \multicolumn{2}{c}{ Kalman filter } & \multicolumn{2}{c}{ Harding-Pagan } \\
\hline & $\mathrm{m}_{\mathrm{t}}$ & $\mathrm{v}_{\mathrm{t}}^{2}$ & $\mathrm{~m}_{\mathrm{t}}$ & $\mathrm{v}_{\mathrm{t}}^{2}$ & $\mathrm{~m}_{\mathrm{t}}$ & $\mathrm{v}_{\mathrm{t}}^{2}$ & $\mathrm{~m}_{\mathrm{t}}$ & $\mathrm{v}_{\mathrm{t}}^{2}$ \\
\hline Mean & 0.031 & 0.029 & 0.086 & 0.149 & 0.041 & 0.033 & 0.009 & 0.032 \\
Median & 0.037 & 0.028 & 0.065 & 0.120 & 0.039 & 0.032 & 0.012 & 0.031 \\
$\mathrm{Q}_{1}$ & 0.010 & 0.021 & 0.008 & 0.071 & 0.015 & 0.023 & -0.019 & 0.018 \\
$\mathrm{Q}_{2}$ & 0.036 & 0.028 & 0.066 & 0.121 & 0.039 & 0.032 & 0.012 & 0.031 \\
$\mathrm{Q}_{3}$ & 0.057 & 0.034 & 0.146 & 0.182 & 0.066 & 0.041 & 0.055 & 0.044 \\
Observations & 345 & 345 & 345 & 345 & 345 & 345 & 345 & 345 \\
\hline
\end{tabular}

Notes: (1) The data are monthly and cover October 1975-March 2004. (2) Q1, Q2, and Q3 stand for first, second, and third quartile, respectively. (3) Core APEC countries in the sample are Japan, South Korea, Malaysia, Mexico, USA, and Canada. 
Table 3 Unit-root tests for Australia, Japan, and South Korea

(c) Level and log-level

\begin{tabular}{ccccccc}
\hline & \multicolumn{2}{c}{ Australia } & \multicolumn{2}{c}{ Japan } & \multicolumn{2}{c}{ South Korea } \\
& $\mathrm{X}_{\mathrm{t}}$ & $\log \left(\mathrm{X}_{\mathrm{t}}\right)$ & $\mathrm{X}_{\mathrm{t}}$ & $\log \left(\mathrm{X}_{\mathrm{t}}\right)$ & $\mathrm{X}_{\mathrm{t}}$ & $\log \left(\mathrm{X}_{\mathrm{t}}\right)$ \\
\hline ADF test & -2.69 & -2.83 & -2.33 & -2.63 & 0.66 & -0.10 \\
P-value & 0.26 & 0.20 & 0.46 & 0.29 & 0.99 & 0.99 \\
Lag & 1 & 1 & 1 & 1 & 1 & 1 \\
Min SC & 3.19 & -5.02 & 3.03 & -5.30 & 3.41 & 3.86 \\
\hline
\end{tabular}

(d) First difference and log-first difference

\begin{tabular}{ccccccc}
\hline & \multicolumn{2}{c}{ Australia } & \multicolumn{2}{c}{ Japan } & \multicolumn{2}{c}{ South Korea } \\
& $\Delta \mathrm{X}_{\mathrm{t}}$ & $\log \left(\Delta \mathrm{X}_{\mathrm{t}}\right)$ & $\Delta \mathrm{X}_{\mathrm{t}}$ & $\log \left(\Delta \mathrm{X}_{\mathrm{t}}\right)$ & $\Delta \mathrm{X}_{\mathrm{t}}$ & $\log \left(\Delta \mathrm{X}_{\mathrm{t}}\right)$ \\
\hline ADF test & -8.59 & -8.34 & -5.60 & -4.89 & -5.94 & -7.15 \\
P-value & 0.00 & 0.00 & 0.00 & 0.00 & 0.00 & 0.00 \\
Lag & 1 & 1 & 1 & 1 & 1 & 1 \\
Min SC & 3.17 & -5.02 & 3.02 & -5.27 & 3.44 & -3.91 \\
\hline
\end{tabular}

Note: (1) ADF and SC stand for Augmented Dickey-Fuller test and Schwartz criterion, respectively. The lag-order for carrying out the ADF test is determined by minimizing the SC. The sample period is 1957:3-2003:4.

Table 4 GMM estimates of $\mathrm{m}_{\mathrm{t}}$ and $\mathrm{v}_{\mathrm{t}}^{2}$ for Australia, Japan, and South Korea

\begin{tabular}{ccccccccc} 
& \multicolumn{2}{c}{ Linear de-trending } & \multicolumn{2}{c}{ Wavelets } & \multicolumn{2}{c}{ Kalman filter } & \multicolumn{2}{c}{ Harding-Pagan } \\
\hline & $\mathrm{m}_{\mathrm{t}}$ & $\mathrm{v}_{\mathrm{t}}^{2}$ & $\mathrm{~m}_{\mathrm{t}}$ & $\mathrm{v}_{\mathrm{t}}^{2}$ & $\mathrm{~m}_{\mathrm{t}}$ & $\mathrm{v}_{\mathrm{t}}^{2}$ & $\mathrm{~m}_{\mathrm{t}}$ & $\mathrm{v}_{\mathrm{t}}^{2}$ \\
\hline Mean & -0.030 & 0.114 & -0.095 & 0.261 & 0.033 & 0.078 & -0.042 & 0.060 \\
Median & -0.034 & 0.100 & -0.134 & 0.157 & 0.025 & 0.053 & -0.063 & 0.054 \\
$\mathrm{Q}_{1}$ & -0.154 & 0.043 & -0.232 & 0.068 & -0.069 & 0.018 & -0.125 & 0.025 \\
$\mathrm{Q}_{2}$ & -0.034 & 0.100 & -0.134 & 0.157 & 0.025 & 0.053 & -0.063 & 0.054 \\
$\mathrm{Q}_{3}$ & 0.060 & 0.181 & 0.028 & 0.370 & 0.127 & 0.115 & 0.011 & 0.085 \\
Observations & 166 & 166 & 166 & 166 & 166 & 166 & 166 & 166 \\
\hline
\end{tabular}

Notes: (1) The data are quarterly and cover 1962:3-2003:3. (2) Q1, Q2, and Q3 stand for first, second, and third quartile, respectively. 
Table $5 \quad$ Unit-root tests for NAFTA countries

(e) Level and log-level of production indices

\begin{tabular}{ccccccccccccc}
\hline & \multicolumn{2}{c}{ Mexico } & \multicolumn{2}{c}{ Mexico } & \multicolumn{2}{c}{ Mexico } & \multicolumn{2}{c}{ US Industrial } & \multicolumn{2}{c}{ US Petroleum } & \multicolumn{2}{c}{ Canada } \\
& \multicolumn{2}{c}{ Manufacturing } & \multicolumn{2}{c}{ Mining } & \multicolumn{2}{c}{ Industrial } & & & & \multicolumn{2}{c}{ Industrial } \\
& $\mathrm{X}_{\mathrm{t}}$ & $\log \left(\mathrm{X}_{\mathrm{t}}\right)$ & $\mathrm{X}_{\mathrm{t}}$ & $\log \left(\mathrm{X}_{\mathrm{t}}\right)$ & $\mathrm{X}_{\mathrm{t}}$ & $\log \left(\mathrm{X}_{\mathrm{t}}\right)$ & $\mathrm{X}_{\mathrm{t}}$ & $\log \left(\mathrm{X}_{\mathrm{t}}\right)$ & $\mathrm{X}_{\mathrm{t}}$ & $\log \left(\mathrm{X}_{\mathrm{t}}\right)$ & $\mathrm{X}_{\mathrm{t}}$ & $\log \left(\mathrm{X}_{\mathrm{t}}\right)$ \\
\hline ADF test & -2.77 & -3.06 & -1.82 & -1.74 & -3.10 & -3.06 & -1.72 & -4.55 & -2.14 & -2.01 & -1.43 & -2.12 \\
P-value & 0.21 & 0.11 & 0.76 & 0.80 & 0.10 & 0.11 & 0.81 & 0.00 & 0.60 & 0.67 & 0.90 & 0.61 \\
Lag & 13 & 16 & 12 & 4 & 13 & 16 & 15 & 12 & 1 & 1 & 1 & 1 \\
Min SC & 4.81 & -3.43 & 5.56 & -2.83 & 4.66 & -3.62 & 2.43 & -5.85 & 4.18 & -5.57 & 2.47 & -5.87 \\
\hline
\end{tabular}

(f) First difference and log-first difference of production indices

\begin{tabular}{ccccccccccccc}
\hline & \multicolumn{2}{c}{ Mexico } & \multicolumn{2}{c}{ Mexico } & \multicolumn{2}{c}{ Mexico } & US Industrial & \multicolumn{2}{c}{ US Petroleum } & \multicolumn{2}{c}{ Canada } \\
& \multicolumn{2}{c}{ Manufacturing } & \multicolumn{2}{c}{ Mining } & \multicolumn{2}{c}{ Industrial } & & & & \multicolumn{3}{c}{ Industrial } \\
& $\Delta \mathrm{X}_{\mathrm{t}}$ & $\log \left(\Delta \mathrm{X}_{\mathrm{t}}\right)$ & $\Delta \mathrm{X}_{\mathrm{t}}$ & $\log \left(\Delta \mathrm{X}_{\mathrm{t}}\right)$ & $\Delta \mathrm{X}_{\mathrm{t}}$ & $\log \left(\Delta \mathrm{X}_{\mathrm{t}}\right)$ & $\Delta \mathrm{X}_{\mathrm{t}}$ & $\log \left(\Delta \mathrm{X}_{\mathrm{t}}\right)$ & $\Delta \mathrm{X}_{\mathrm{t}}$ & $\log \left(\Delta \mathrm{X}_{\mathrm{t}}\right)$ & $\Delta \mathrm{X}_{\mathrm{t}}$ & $\log \left(\Delta \mathrm{X}_{\mathrm{t}}\right)$ \\
\hline ADF test & -4.70 & -4.78 & -6.86 & -17.3 & -4.48 & -4.62 & -5.00 & -4.72 & -16.7 & -16.9 & -13.6 & -13.7 \\
P-value & 0.00 & 0.00 & 0.00 & 0.00 & 0.00 & 0.00 & 0.00 & 0.00 & 0.00 & 0.00 & 0.00 & 0.00 \\
Lag & 12 & 15 & 11 & 3 & 12 & 15 & 14 & 13 & 1 & 1 & 1 & 1 \\
Min SC & 4.77 & -3.47 & 5.50 & -2.87 & 4.62 & -3.65 & 2.38 & -5.89 & 4.16 & -5.60 & 2.43 & -5.89 \\
\hline
\end{tabular}

Note: (1) ADF and SC stand for Augmented Dickey-Fuller test and Schwartz criterion, respectively. The lag-order for carrying out the ADF test is determined by minimizing the SC. The sample period is January 1971-March 2004

Table 6 GMM estimates of $m_{t}$ and $v_{t}^{2}$ for NAFTA countries

\begin{tabular}{ccccccccc} 
& \multicolumn{2}{c}{ Linear de-trending } & \multicolumn{2}{c}{ Wavelets } & \multicolumn{2}{c}{ Kalman filter } & \multicolumn{2}{c}{ Harding-Pagan } \\
\hline & $\mathrm{m}_{\mathrm{t}}$ & $\mathrm{v}_{\mathrm{t}}^{2}$ & $\mathrm{~m}_{\mathrm{t}}$ & $\mathrm{v}_{\mathrm{t}}^{2}$ & $\mathrm{~m}_{\mathrm{t}}$ & $\mathrm{v}_{\mathrm{t}}^{2}$ & $\mathrm{~m}_{\mathrm{t}}$ & $\mathrm{v}_{\mathrm{t}}^{2}$ \\
\hline Mean & 0.182 & 0.074 & 0.173 & 0.228 & 0.182 & 0.073 & 0.087 & 0.084 \\
Median & 0.183 & 0.074 & 0.182 & 0.174 & 0.182 & 0.073 & 0.090 & 0.081 \\
$\mathrm{Q}_{1}$ & 0.143 & 0.067 & 0.122 & 0.126 & 0.144 & 0.066 & 0.048 & 0.053 \\
$\mathrm{Q}_{2}$ & 0.183 & 0.074 & 0.182 & 0.174 & 0.182 & 0.073 & 0.090 & 0.081 \\
$\mathrm{Q}_{3}$ & 0.236 & 0.082 & 0.237 & 0.266 & 0.236 & 0.082 & 0.123 & 0.107 \\
Observations & 353 & 353 & 353 & 353 & 353 & 353 & 353 & 353 \\
\hline
\end{tabular}

Note: (1) The data are monthly and cover November 1974-March 2004. The indices include the Mexican mining, manufacturing, and industrial production sectors, the US industrial and crude petroleum production sectors indices and the Canadian industrial production sector. (2) Q1, Q2, and Q3 stand for first, second, and third quartile, respectively. 
Table 7 Descriptive statistics of Spearman's rank correlation

\begin{tabular}{ccccc}
\hline \multicolumn{5}{c}{ (a) Core sampled APEC countries } \\
\hline & Linear de-trending & Wavelets & Kalman filter & Harding-Pagan \\
\hline Mean & 0.321 & 0.298 & 0.300 & 0.306 \\
Median & 0.312 & 0.323 & 0.300 & 0.305 \\
$\mathrm{Q}_{1}$ & 0.294 & 0.240 & 0.287 & 0.296 \\
$\mathrm{Q}_{2}$ & 0.312 & 0.323 & 0.300 & 0.305 \\
$\mathrm{Q}_{3}$ & 0.344 & 0.346 & 0.311 & 0.316 \\
Observations & 216 & 216 & 216 & 216 \\
\multicolumn{5}{c}{ (b) Australia, Japan, and South Korea } \\
\hline Mean & 0.370 & 0.432 & 0.381 & 0.257 \\
Median & 0.370 & 0.429 & 0.380 & 0.255 \\
$\mathrm{Q}_{1}$ & 0.293 & 0.383 & 0.320 & 0.204 \\
$\mathrm{Q}_{2}$ & 0.370 & 0.429 & 0.380 & 0.255 \\
$\mathrm{Q}_{3}$ & 0.438 & 0.462 & 0.491 & 0.304 \\
Observations & 124 & 124 & 124 & 124 \\
\multicolumn{5}{c}{ (c) NAFTA countries } \\
\hline Mean & Linear de-trending & Wavelets & Kalman filter & Harding-Pagan \\
\hline Median & 0.357 & 0.337 & 0.360 & 0.319 \\
$\mathrm{Q}_{1}$ & 0.364 & 0.347 & 0.366 & 0.318 \\
$\mathrm{Q}_{2}$ & 0.334 & 0.302 & 0.339 & 0.311 \\
$\mathrm{Q}_{3}$ & 0.364 & 0.347 & 0.366 & 0.318 \\
Observations & 0.387 & 0.382 & 0.389 & 0.328 \\
\hline
\end{tabular}

Notes: (1) In Panels (a)-(c), we use a rolling-window of 7 years for the linear de-trending, wavelet, and Kalman filter methods, and a rolling window of 14 years for the Harding-Pagan procedure. The lag between observations is 2 years. The sample periods for Panels (a)-(c) are, respectively, April 1986-March 2004, 1973:1-2003:4, and April 1985-March 2004. (2) Q1, Q2, and Q3 stand for first, second, and third quartile, respectively. 


\section{DAVIDSON INSTITUTE WORKING PAPER SERIES - Most Recent Papers}

The entire Working Paper Series may be downloaded free of charge at: www.wdi.bus.umich.edu

CURRENT AS OF 4/14/05

\begin{tabular}{|c|c|c|}
\hline Publication & Authors & Date \\
\hline $\begin{array}{l}\text { No. 765: Do Regional Integration Agreements Increase Business-Cycle } \\
\text { Convergence? Evidence From APEC and NAFTA }\end{array}$ & $\begin{array}{l}\text { Viviana Fernandez and Ali M. } \\
\text { Kutan }\end{array}$ & Apr. 2005 \\
\hline $\begin{array}{l}\text { No. 764: State Regulations, Job Search and Wage Bargaining: A Study } \\
\text { in the Economics of the Informal Sector }\end{array}$ & Maxim Bouev & Apr. 2005 \\
\hline $\begin{array}{l}\text { No. 763: The Feldstein-Horioka Puzzle Revisited: An “European- } \\
\text { Regional” Perspective }\end{array}$ & $\begin{array}{l}\text { Jérôme Hericourt and Mathilde } \\
\text { Maurel }\end{array}$ & Apr. 2005 \\
\hline $\begin{array}{l}\text { No. 762: Transatlantic Differences in Labour Markets Changes in Wage } \\
\text { and Non-Employment Structures in the 1980s and the 1990s }\end{array}$ & Patrick A. Puhani & Mar. 2005 \\
\hline $\begin{array}{l}\text { No. 761: Resolution, Recovery and Survival: The Evolution of Payment } \\
\text { Disputes in Post-Socialist Europe }\end{array}$ & William Pyle & Mar. 2005 \\
\hline $\begin{array}{l}\text { No. 760: Official Foreign Exchange Interventions in the Czech } \\
\text { Republic: Did They Matter? }\end{array}$ & Balázs Égert and Luboš Komárek & Mar. 2005 \\
\hline $\begin{array}{l}\text { No. 759: Assessing Market Expectations on Exchange Rates and } \\
\text { Inflation: A Pilot Forecasting System for Bulgaria }\end{array}$ & $\begin{array}{l}\text { Michael Berlemann, Kalina } \\
\text { Dimitrova, \& Nikolay Nenovsky }\end{array}$ & Mar. 2005 \\
\hline No. 758: Attitudes and Performance: An Analysis of Russian Workers & $\begin{array}{l}\text { Susan J. Linz and Anastasia } \\
\text { Semykina }\end{array}$ & Mar. 2005 \\
\hline $\begin{array}{l}\text { No. 757: Barter, Credit, and Welfare: A theoretical inquiry into the } \\
\text { barter phenomenon in Russia }\end{array}$ & José Noguera and Susan J. Linz & Mar. 2005 \\
\hline $\begin{array}{l}\text { No. 756: Sorting, Selection, and Transformation of the Return to } \\
\text { College Education In China }\end{array}$ & $\begin{array}{l}\text { Belton M. Fleisher, Haizheng Li, } \\
\text { Shi Li, and Xiaojun Wang }\end{array}$ & Mar. 2005 \\
\hline $\begin{array}{l}\text { No. 755: Foreign Exchange Interventions in Emerging Europe: } \\
\text { Should We Give a Damn? The Case of Croatia and Turkey }\end{array}$ & Balázs Égert and Maroje Lang & Mar. 2005 \\
\hline $\begin{array}{l}\text { No. 754: Targeting Relative Inflation Forecast as Monetary Policy } \\
\text { Framework for Adopting Euro }\end{array}$ & Lucjan T. Orlowski & Feb. 2005 \\
\hline $\begin{array}{l}\text { No. 753: Internet Entrepreneurship: Networks and Performance of } \\
\text { Internet Ventures In China }\end{array}$ & Bat Batjargal & Feb. 2005 \\
\hline $\begin{array}{l}\text { No. 752: Network Triads: Transitivity, Referral and Venture Capital } \\
\text { Decisions in China and Russia }\end{array}$ & Bat Batjargal & Feb. 2005 \\
\hline $\begin{array}{l}\text { No. 751: Software Entrepreneurship: Knowledge Networks and } \\
\text { Performance Of Software Ventures In China and Russia }\end{array}$ & Bat Batjargal & Feb. 2005 \\
\hline $\begin{array}{l}\text { No. 750: Retained State Shareholding in Chinese PLCs: Does } \\
\text { Government Ownership Reduce Corporate Value? }\end{array}$ & Lihui Tian and Saul Estrin & Feb. 2005 \\
\hline No. 749: Financial Development and Technology & Solomon Tadesse & Feb. 2005 \\
\hline No. 748: Banking Fragility and Disclosure: International Evidence & Solomon Tadesse & Feb. 2005 \\
\hline $\begin{array}{l}\text { No. 747: Consolidation, Scale Economies and Technological Change in } \\
\text { Japanese Banking }\end{array}$ & Solomon Tadesse & Feb. 2005 \\
\hline $\begin{array}{l}\text { No. 746: Trade Creation and Diversion Effects of Europe’s Regional } \\
\text { Liberalization Agreements }\end{array}$ & Yener Kandogan & Feb. 2005 \\
\hline No. 745: Quality of Institutions, Credit Markets and Bankruptcy & Christa Hainz & Feb. 2005 \\
\hline $\begin{array}{l}\text { No. 744: How Transition Paths Differ: Enterprise Performance in Russia } \\
\text { and China }\end{array}$ & Sumon Bhaumik and Saul Estrin & Jan. 2005 \\
\hline $\begin{array}{l}\text { No. 743: Inflation Targeting, Between Rhetoric and Reality. The Case } \\
\text { of Transition Economies }\end{array}$ & Daniel Daianu and Laurian Lungu & Jan. 2005 \\
\hline $\begin{array}{l}\text { No. 742: How Does Law Affect Finance? An Empirical Examination of } \\
\text { Tunneling in an Emerging Market }\end{array}$ & $\begin{array}{l}\text { Vladimir Atanasov, Conrad S. } \\
\text { Ciccotello, \& Stanley B. Gyoshev }\end{array}$ & Jan. 2005 \\
\hline $\begin{array}{l}\text { No. 741: Do Insider Trading Laws Matter? Some Preliminary } \\
\text { Comparative Evidence }\end{array}$ & Laura Nyantung Beny & Jan. 2005 \\
\hline $\begin{array}{l}\text { No. 740: Autopsy on an Empire: Understanding Mortality in Russia and } \\
\text { the Former Soviet Union }\end{array}$ & $\begin{array}{l}\text { Elizabeth Brainerd and David M. } \\
\text { Cutler }\end{array}$ & Jan. 2005 \\
\hline $\begin{array}{l}\text { No. 739: Not Separate, Not Equal: Poverty and Inequality in Post- } \\
\text { Apartheid South Africa }\end{array}$ & $\begin{array}{l}\text { Johannes G. Hoogeveen and Berk } \\
\text { Özler }\end{array}$ & Jan. 2005 \\
\hline $\begin{array}{l}\text { No. 738: The Marketing Structure in Agribusiness during the Transition } \\
\text { in Bulgaria }\end{array}$ & $\begin{array}{l}\text { Steve Murray, Yordan Staykov, } \\
\text { and Valentin Katzerov }\end{array}$ & Jan. 2005 \\
\hline
\end{tabular}

